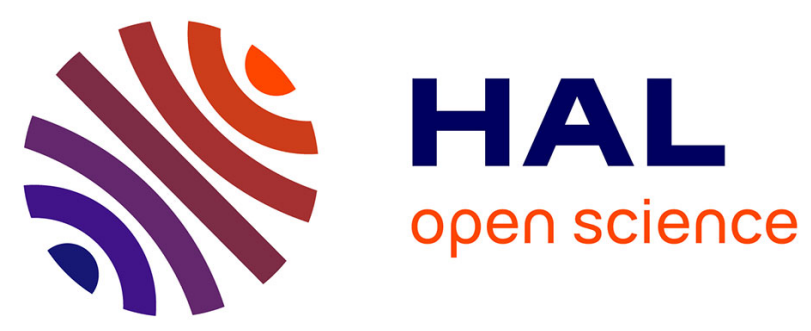

\title{
Detrital-zircon ages and geochemistry of sedimentary rocks in basement Mesozoic terranes and their cover rocks in New Caledonia, and provenances at the Eastern Gondwanaland margin
}

\author{
C.J. Adams, Dominique Cluzel, W.L. Griffin
}

\section{To cite this version:}

C.J. Adams, Dominique Cluzel, W.L. Griffin. Detrital-zircon ages and geochemistry of sedimentary rocks in basement Mesozoic terranes and their cover rocks in New Caledonia, and provenances at the Eastern Gondwanaland margin. Australian Journal of Earth Sciences, 2009, 56 (8), pp.1023-1047. insu-00433793

\section{HAL Id: insu-00433793 \\ https://hal-insu.archives-ouvertes.fr/insu-00433793}

Submitted on 20 Nov 2009

HAL is a multi-disciplinary open access archive for the deposit and dissemination of scientific research documents, whether they are published or not. The documents may come from teaching and research institutions in France or abroad, or from public or private research centers.
L'archive ouverte pluridisciplinaire HAL, est destinée au dépôt et à la diffusion de documents scientifiques de niveau recherche, publiés ou non, émanant des établissements d'enseignement et de recherche français ou étrangers, des laboratoires publics ou privés. 
*Corresponding author: Dr Christopher J. Adams, GNS Science, Private Bag 1930, Dunedin, New

Zealand. Email argon@gns.cri.nz, Tel. 00643 4774050, Fax 006434775232.

\section{Detrital zircon ages and geochemistry of sedimentary}

\section{rocks in basement Mesozoic terranes and their cover}

rocks in New Caledonia, and provenances at the Eastern

\section{Gondwanaland margin.}

\section{J. ADAMS $^{1 *}$, D. CLUZEL ${ }^{2-3,}$ AND W. L. GRIFFIN ${ }^{4}$}

${ }^{1}$ GNS Science, Private Bag 1930, Dunedin, New Zealand.

${ }^{2}$ The University of New Caledonia, PPME, EA 3325, Noumea New Caledonia.

${ }^{3}$ University of Orleans, CNRS/INSU, University François Rabelais - Tours

Institut des Sciences de la Terre d'Orléans - UMR 6113, France.

${ }^{4} A R C$ Key Centre for Geochemical Evolution and Metallogeny of Continents, Department of Earth and Planetary Sciences, Macquarie University, North Ryde, NSW 2109, Australia.

Geochemical and Sr-Nd isotope data for Mesozoic greywackes of New Caledonia terranes, indicate a fore-arc tectonic environment at the Eastern Gondwanaland margin, but they support only minor continental influences. Detrital zircon U-Pb age 
patterns for the greywackes similarly reflect an active-margin tectonic environment of Late Triassic, Late Jurassic, and in particular mid-Cretaceous, depocentres which comprise much contemporaneous volcanic detritus, but also include minor sediment inputs from early Paleozoic-Precambrian continental clastic rocks. The contemporary volcanic sources are probably now hidden within a former hinterland to New Caledonia, such as Loyalty and Norfolk Ridges, Lord Howe Rise or Marion Plateau. The older, continental sediment sources were probably in northeasternmost Queensland, and beyond the northern extremity of the New England Orogen. Such sediments could have been supplied on long rivers, and submarine long-shore current systems outboard of the orogen. Alternatively, the depocentres could have been consolidated close to the contemporary Gondwanaland margin and then tectonically transported, as suspect terranes, southwards in Early Cretaceous times to their present New Caledonia position.

KEY WORDS: New Caledonia, Gondwanaland, Mesozoic, volcaniclastic sedimentary rocks, geochronology, detrital zircon, geochemistry, strontium isotopes, neodymium isotopes.

\section{INTRODUCTION}

Situated at the Pacific edge of the Mesozoic Australasian continent crust, New Caledonia and New Zealand provide two comparable sectors of the former, late Paleozoic-Mesozoic Gondwanaland continental margin (Fig.1 inset). New Zealand and New Caledonia are part of a large, but mostly submerged, continental crustal block, 'Zealandia'. This extends from the Chatham Rise and Campbell Plateau (southwest Pacific Ocean), through New Zealand, the Challenger Plateau and Lord Howe Rise, to 
New Caledonia. It has been extensively studied New Zealand where the Zealandia basement comprises Paleozoic and Mesozoic sedimentary rocks, active-margin volcanic arcs, and associated plutonic complexes. These are divided into an early Paleozoic, Western Province, clearly related to the Lachlan Fold Belt of southeast Australia, and an Eastern Province, which comprises six late Paleozoic-Mesozoic elongate, tectonostratigraphic terranes. Situated between Western and Eastern Provinces, a Median Batholith, of Permian-Cretaceous plutonic rocks (Bishop et al. 1985, Mortimer et al. 1999), may be correlated with the more extensive Carboniferous-Jurassic igneous complexes within the New England Fold Belt of northeast Australia,

The Eastern Province terranes of New Zealand comprise an eastern group (Torlesse, Waipapa and Caples) of Permian to Cretaceous, greywacke-dominated turbiditic sequences deposited in an accretionary prism environment (Bishop et al. 1985). The easternmost, Torlesse Terrane is dominated by relatively quartzose greywacke sediments derived from continental sources which included plutonic and metamorphic rocks (MacKinnon 1985), whilst the Waipapa and Caples Terranes (Sporli 1978, Turnbull, 1979) have more acid-intermediate volcaniclastic sediment inputs, and resemble those of the New Caledonia Central Terrane. The remaining, western, terrane group (Dun Mountain-Maitai, Murihiku, Brook Street), has mainly Permian, Triassic and Jurassic, redeposited volcaniclastic greywacke-dominated successions (Ballance \& Campbell 1993, Landis et al. 1999), but in a more shallow-water, probable forearc setting. The Brook Street terrane includes substantial volcanic centres and some minor limestones (probably shallow-water). The Dun Mountain-Maitai terrane contains the major Dun Mountain Ophiolite Belt (Coombs et al. 1976), and also has some limestones 
(calc-turbidites). In contrast, the Murihiku Terrane is dominated by volcaniclastic sediments with no limestones, and only rare volcanic horizons. It has excellent biostratigraphic subdivision (Ballance \& Campbell 1993), whose faunas closely resemble those of the Teremba Terrane of New Caledonia (Campbell et al. 1985). Extensive references and details of biostratigraphy, geochemistry and geochronology of the Eastern Province terranes that are relevant to possible correlations with their New Caledonia counterparts are given in Mackinnon (1985), Roser \& Korsch (1988, 1999), Adams et al. (2007). The relative position of the terranes with respect to the Gondwanaland continental margin, suggests that several, especially the Torlesse composite terrane, are suspect terranes i.e. tectonically displaced from elsewhere along the Gondwanaland margin. Original sedimentary depocentres have been suggested in the New Zealand-West Antarctic region (Cawood et al. 1999, Wandres et al. 2004a,b). Alternatively, original depocentres in the northeastern Australian sector have been suggested (Ireland 1992, Pickard et al 2000, Adams et al. 2007), where there are superior matches of Eastern Province detrital zircon age patterns with appropriate sediment sources.

Despite their similarities in age, tectonic setting, sedimentary petrography and biostratigraphy, the exact relationships between New Zealand and New Caledonia terranes remain unclear. The disposition of New Caledonia terranes with respect to the Gondwana continental margin suggests that a suspect terrane scenario is also possible, similar to that described above for the Eastern Province of New Zealand. Thus to investigate their connection further, we present here new geochemical and detrital zircon age data for greywackes from three pre-Late Cretaceous terranes in New 
Caledonia, and compare their sediment provenances with those from terranes of similar age and tectonic association in New Zealand.

\section{NEW CALEDONIA: GEOLOGICAL OUTLINE}

Two major terrane groups are distributed along the length of New Caledonia (Fig.1): an

older, Late Permian to Early Cretaceous group of three_subparallel, elongate terranes on the west coast (Teremba) and in the central mountain chain (Koh-Central, and Boghen); and a younger Late Cretaceous to Oligocene group, overlying the latter, that formed in response to break-up, drift, and subsequent collision of, an island arc (Aitchison et al, 1995). The pre-Late Cretaceous terranes were formed during a period of accretion, and show the closest biostratigraphic correspondences with Eastern Province terranes of New Zealand.

The three terranes that form the central mountains of New Caledonia are as follows:

(1) Koh-Central Terrane: a disrupted, Early Permian ophiolite suite occurs locally along the centre of the island, comprising gabbro, dolerite, rare plagiogranite, IAT and boninite pillow basalt, and undated chert directly overlying the pillow basalts (the Koh ophiolite of Meffre et al. 1996). The Koh ophiolite rocks are closely associated with a thick deep-water succession of volcanosedimentary rocks: black shale, volcaniclastic turbidite (greywacke), radiolarian-bearing siltstone and chert. These sequences are regarded as a single terrane (Meffre et al. 1996; Aitchison et al., 1998). The black shales are several hundred metres thick, whilst greywackes are generally associated with $20-50 \%$ argillite, giving this terrane a distal and deep-water character. The 
greywackes are exclusively composed of volcanic lithic (andesite and basalt) and mineral clasts (feldspar, quartz, amphibole, etc.), and plutonic clasts are generally absent, except for one locality (late Early Cretaceous). Middle Triassic (Anisian), and Late Jurassic faunas are correlated with those of the New Zealand Murihiku Terrane (Campbell et al., 1985; Meffre, 1995). Recently, a fossiliferous succession at Pouembout, formerly considered Late Jurassic, is now considered Early Cretaceous (H.J. Campbell (pers. comm.).

(2) Teremba (formerly Teremba-Moindou) Terrane: a succession of very lowgrade (zeolite facies), Late Permian to mid-Jurassic, shallow-water, volcaniclastic (calc-alkaline, island arc-derived, andesitic) sedimentary rocks and volcanics (andesites, dacites and rhyolites). The sedimentary rocks are typically medium grain greywackes with only minor $(<10 \%)$ intercalated argillite, some shallow water volcaniclastic conglomerate and rare black shale, a few tens metres thick. The mineral composition of greywackes is closely similar to that of Central Terrane and similarly lack plutonic clasts. This terrane also contains abundant faunas resembling those of the Murihiku Terrane of New Zealand (Grant-Mackie et al., 1977; Paris 1981, Campbell, 1984, Ballance \& Campbell, 1993).

(3) Boghen Terrane: (the ante-Permien of Paris, 1981), an accretionary complex comprising schistose unfossiliferous, volcano-sedimentary rocks (pillow basalts, chert, black shale, sandstone, tuffs, turbiditic greywackes, and mafic melange), at a metamorphic grade (lower greenschist to blueschist facies) that is notably higher than the adjacent terranes. Late Jurassic metamorphic ages 
(ca. $150 \mathrm{Ma}$, whole-rock K-Ar) of the blueschists and metabasalt (Blake et al., 1977) suggest a minimum mid-Jurassic age for metamorphism, and Early Jurassic detrital zircon ages (Cluzel \& Meffre, 2002) set a maximum depositional age for the original sediments. However, zircon U-Pb ages of this present work infer a much younger maximum depositional age at ca. 135 Ma (Early Cretaceous). This discrepancy may arise from limitations of the KAr whole-rock dating method used (Blake et al. 1977), where presence of excess Ar is possible, and thus the Late Jurassic metamorphic age is rejected here.

Since Triassic to Early Cretaceous shallow-water volcaniclastic sediments occur to the west, and deeper-water sediments (with the same origin) to the east, and volcanic rocks and shallow intrusions are absent in the Central Terrane, Meffre (1995) and Cluzel \& Meffre (2002) have suggested that the Teremba and Central Terranes are respectively the onshore and offshore parts of the same fore-arc basin. This view is also supported by a westwardsincreasing metamorphic gradient in the HP-LT Boghen terrane (Guérangé et al., 1975; Paris, 1981), thus implying westwards-dipping Mesozoic subduction.

Unconformably overlying the three above-mentioned terranes, there is a prominent Late Cretaceous (Coniacian to Maastrichtian), volcanosedimentary unit (classically referred to as Formation à Charbon) composed of marine shallow water sandstone, coal-bearing siltstone, tuffs and volcanic rocks. Sandstones of 
this unit contain detrital zircon populations which have a dominant (c. 70\%) component at 90-140 Ma, and a minor (c. 25\%) component at 170-240 Ma (Aitchison et al., 1998). From probable correlative (Late Cretaceous) sandstones at Dumbéa River, Aronson \& Tilton (1971) obtained discordant U-Pb zircon data that suggested dominant Late Cretaceous, and accessory Precambrian (>1000 Ma) age components. The occurrence of unconformable Late Cretaceous sediments upon terranes whose greywackes contain reworked Early Cretaceous zircons suggest that the pre-Late Cretaceous terranes were amalgamated in early Late Cretaceous time.

\section{TECHNICAL METHODS}

Samples were initially collected for geochemical and isotopic analysis of both sedimentary rocks, and volcanic horizons in the three New Caledonia terranes. The analytical procedures relating to this study are described in the Appendix 1.

A small group of representative sandstone samples from the three basement terranes, and the Cretaceous cover sequences, were also collected for detrital zircon studies, preferably from localities, or general areas where there was reasonable biostratigraphic control. Details of detrital zircon preparation procedures, LAM-ICPMS dating techniques, and $\mathrm{U}-\mathrm{Pb}$ data treatment are listed in Appendix 1.

\section{GEOCHEMISTRY OF GREYWACKES AND VOLCANIC ROCKS}


Geochemical analyses of 16 volcanic rocks from Teremba Terrane and 21 greywacke samples from Teremba and Central Terranes are used here to constrain their origins. Permian volcanic rocks of the Teremba Terrane are mainly represented by ash fall deposits and/or pyroclastic flows (surge deposits) with occasional massive rhyolite and andesite, whereas Mesozoic volcanics (mainly Triassic) are dacitic to rhyolitic with many hypabyssal intrusions and only a few subaerial volcanic rocks and rare pillow lavas. In the Central terrane, the only volcanic rocks are scarce, massive, island-arc basalts (Meffre, 1995). Consistent with field observations, the major element compositions range from basalt-andesite to rhyolite (Table 1b). However, the trace element patterns allow tholeiitic and calc-alkaline suites to be distinguished. REE patterns (Pearce, 1982, not presented) for tholeiites are generally flat and slightly depleted in LREE, but, in contrast, calc-alkaline rocks are typically enriched in LREE (La to Sm), with the rest of the pattern similar to that of tholeiites. On a REE/trace element expanded spider-diagram (Sun \& McDonough, 1989) (Fig. 2), all these rocks are enriched in LILE and typically display a prominent negative $\mathrm{Nb}-\mathrm{Ta}$ anomaly, of which tholeiites (island-arc tholeiites) have the lowest incompatible element content.

Except for the occurrence of biogenic carbonate in some samples, that result in relatively low $\mathrm{SiO}_{2}$ and high $\mathrm{CaO}$ contents (Table 1a), the greywackes, that are almost exclusively composed of volcanic lithic and mineral clasts, logically display geochemical features that are strikingly similar to those of the volcanic rocks. However, on average, the volcanic rocks sampled here are probably more mafic than the bulk of the sediment sources of the greywackes. A few of them display almost flat REE patterns, whereas the rest are enriched in LREE to various degrees. However, the bulk 
REE content is more variable in the volcaniclastic sediments than in volcanic rocks, a possible consequence of limited dilution by weathering products and pelagic sediments. REE/trace elements patterns are closely similar to that of volcanic rocks (Fig. 2) and similarly indicate a volcanic-arc origin. Owing to the clastic mineral composition and similar geochemical features, greywackes and volcanic rocks appear to be derived from a similar magmatic source. Considering the westward coarsening and absence of erosion features within Mesozoic series, the greywackes are most likely derived from the erosion of volcanic rocks and coeval plutonic or shallow intrusive rocks which are now located to the west of present-day New Caledonia, e.g. in the Lord Howe Rise (Cluzel \& Meffre, 2002).

\section{ND-SR ISOTOPE GEOCHEMISTRY OF GREYWACKES}

12 greywacke samples were selected for isotope analysis in order to identify their source rocks. In order to remove the biogenic carbonate which is obvious in some greywackes, all analysed samples have been leached with cold acetic acid. Most of them plot within a very narrow range of variation (Fig. 3) with positive $\varepsilon N d(+0.9<\varepsilon \mathrm{Nd}<+3)$ and low

$\varepsilon \operatorname{Sr}(-4<\varepsilon \mathrm{Sr}<+25)$ values, that are typical of magmatic rocks derived from an undepleted mantle source with no evidence of contamination by sediment or continental crust rocks. Two samples display slightly negative $\varepsilon \mathrm{Nd}$ values $(-6.7<\varepsilon \mathrm{Nd}<-2.8)$ whereas $\varepsilon \mathrm{Sr}$ remains only slightly positive $(+9.5<\varepsilon \mathrm{Sr}<+25)$, implying a very limited contamination by a lower continental crust component. Only one sample displays a positive $\varepsilon \operatorname{Sr}(+212)$ together with a high $\mathrm{Th}$ content $(13.8 \mathrm{ppm})$ consistent with the 
involvement of a terrigenous (sedimentary) component, either by contamination of the mantle source, or more probably by mixing of the volcaniclastic component with a small amount of terrigenous argillite. It is worth noting that such differences in isotope ratios are not accompanied by noticeable geochemical changes (see Fig 2).

In summary, the Mesozoic greywackes are derived from a volcanic-arc source with almost no contamination by continental crust or pelagic sediment. As already pointed out by Meffre (1995), the original material (andesite, dacite and/or rhyolite) is similar to that of most intra-oceanic volcanic arcs; therefore, Permian-Mesozoic volcanic-arc magmas may have been erupted through an oceanic lithosphere or a thinned/intermediate continental crust rather than in a "normal" continental active margin. If this is the case, then any older zircons (pre-Permian) must be recycled either from older sediments derived from continental sources, or entrained as xenoliths within deep primary sources of unknown location. Thus, it appears likely that, as proposed by Cluzel \& Meffre (2002), Central and Teremba terrane sediments accumulated in a fore arc region, partly upon a trapped oceanic crust element now represented by the Koh ophiolite (Fig. 1).

\section{DETRITAL ZIRCON GEOCHRONOLOGY}

Detrital zircon U-Pb age data for greywackes from nine localities (Table 3) in three New Caledonia terranes are presented in three forms.

Firstly, in Figs. 4-1 to $4-9$, all ${ }^{206} \mathrm{~Pb} /{ }^{238}$ zircon ages are treated with equal weight as combined probability density/histogram diagrams for each sample. These diagrams show individual points of detail well, but taken together, the nine diagrams are difficult 
to compare visually. Thus, secondly, a summary table (Table 4) lists only those ages that form statistically significant components on the probability density plots of Fig. 4 (see also Appendix 2), and these are then displayed in Fig. 5, taking into consideration their proportional contribution to the total zircon set. Thirdly, in Tables 5A, and 6A, all ages of the New Caledonia age datasets are used, by displaying the percentage of the zircon ages that fall within selected geological periods. In these diagrams, the data are compared with published datasets from New Zealand Eastern Province terranes (Table 5B) and selected northeastern Australian terranes (Table 6B) (Adams et al. 2007, Korsch et al. 2008 in press).

\section{Formation á Charbon}

Sandstone at locality (1), correlative with Formation à Charbon nearby, has dominant Cretaceous ( $>80 \%)$, and a minor, Triassic-Jurassic (12\%) zircon groups, but few (5\%) Precambrian zircon ages (Fig. 4-1, Fig. 5, and Table 5A). The small, youngest zircon age component, $85 \pm 2 \mathrm{Ma}$, is in agreement with the estimated Coniacian-Santonian age, but this is overwhelmed ( $>70 \%)$ by several mid- and Early Cretaceous subcomponents, $95 \pm 1,102 \pm 4,110 \pm 2,119 \pm 2$ and $130 \pm 2 \mathrm{Ma}$. These latter clearly reflect reworking of a long-lived active Cretaceous igneous province, relatively isolated from older, 'continental' inputs. Whilst the youngest zircons are probably derived from contemporaneous, dacite-rhyolite volcanic sources, c.85 Ma, it is probable that the older dominant group at 100-120 Ma reflects erosion not only of older parts of the igneous province but also reworking of detrital zircons from underlying Albian greywackes, 
such as those at locality (2) (see below). The latter might also contribute the few inherited, Precambrian zircons.

\section{Central Terrane}

Central Terrane greywackes at localites (2) and (3) have quite dissimilar detrital zircon age patterns.

The locality (2) was originally mapped as a Late Jurassic succession within the terrane, but arising from the new Cretaceous zircon age data below, a closer search yielded Early Cretaceous fossils (H. Campbell pers. comm.). Its zircon age pattern is similar to that of Formation á Charbon at locality (1), with dominant Cretaceous ( $>80 \%)$, and minor (11\%) Precambrian, groups (Fig. 4-1, Fig. 5, and Table 5A). Within the Cretaceous group, the youngest statistically significant age component, $108 \pm 2 \mathrm{Ma}$, is the major one, and provides a maximum Albian age for deposition, supporting the new fossil age assignment.

In contrast, the Late Jurassic locality (3) has far fewer (28\%) contemporary zircons (a single statistically significant component is $162 \pm 3 \mathrm{Ma}$ ), and a dramatically increased early Paleozoic-Precambrian proportion ( $>70 \%$ ), with age components at $513 \pm 5,539 \pm 6$, $557 \pm 5$, and $592 \pm 5 \mathrm{Ma}$.

\section{Boghen Terrane}

The zircon age pattern for the Boghen terrane greywacke (4) is similar to the Late Jurassic, Central (11), and Late Triassic Teremba (6) Terrane samples, having low $(<25 \%)$ proportions of contemporary zircons, and high proportions $(>40 \%)$ of inherited, 
early Paleozoic-Precambrian zircons (Table 5A). Significant older zircon component ages are Cambrian-late Neoproterozoic, $505 \pm 4,563 \pm 6$, and $584 \pm 5 \mathrm{Ma}$, similar to those in Central (3) and Teremba $(5,6,8)$ Terrane samples. At this locality, the greywacke depositional age is uncertain, but the youngest zircon age group, at $170 \pm 2 \mathrm{Ma}$ (which is just statistically significant), suggests a Middle Jurassic maximum. However, three younger individual ages, $137 \pm 2,141 \pm 2$ and $149 \pm 2$ Ma reduce this to Early CretaceousLate Jurassic.

\section{Teremba Terrane}

The Teremba Terrane samples from localities (5)-(8) have their youngest zircon ages close to their estimated Middle-Late Triassic depositional ages (Figs. 4-5 to 4-8, and Table 5A), and with the exception of locality (8), these form statistically significant age components. They thus probably reflect contemporary volcanic-arc sources. This would be particularly true of greywacke at locality (7), which unlike the remainder of the terrane samples, has an extremely high proportion (96\%) of Triassic zircons, with the youngest age component, comprising $33 \%$ of the total, at $225 \pm 2$ Ma (Late Triassic, Norian). An age discrepancy is apparent in the sample from locality (6). This is mapped within an area of Middle Triassic rocks (237-245 Ma), although four zircon ages c. 215 $\mathrm{Ma}$ (Fig. 5) are clearly younger than this, and suggest that the sample is from a horizon no older than Late Triassic (Norian). With the exception of locality (7), the remaining Teremba Terrane samples have major proportions $(>50 \%)$ of early Palaeozoic and Precambrian zircons and several statistically significant age components falling in the latest Neoproterozoic, c. 550-590 Ma (Fig. 5). 


\section{DISCUSSION}

None of the New Caledonia terranes have sandstones with detrital zircon age patterns sufficiently distinctive to discriminate one terrane from another (Fig. 5). Rather, all the zircon patterns fall between two extremes: those dominated by contemporary, volcanic (Fig. 5: 2, 7) sources, and those by inherited, continental (Fig. 5: 4, 8) sources. In this sense, it could be argued that all the terranes had broadly similar depocentres, capable of providing both substantial contemporary volcaniclastic detritus, from island-arc centres (perhaps local) and terrigenous clastic material from an old hinterland of continental character (perhaps more distant). However, the sandstones dominated by contemporary volcanic inputs are more typically Cretaceous, whilst those dominated by inherited inputs are all pre-Cretaceous. This may indicate that New Caledonia became more isolated from direct continental zircon sources in the late Early Cretaceous, probably at a time of extension, before major rifting created Tasman Sea ocean floor at c. $85 \mathrm{Ma}$ (Santonian). Alternatively, the contemporary Cretaceous volcanism may have been so dominant as to completely overwhelm any continuing continental zircon inputs. The zircon sources of the contemporary volcanic and older inherited continental components are thus discussed separately below.

\section{Contemporary zircon sources for sediments in the New Caledonia region}

Those youngest zircon age components in the Central and Teremba terrane greywacke samples that overlap estimated depositional ages, probably originate in contemporary volcanic centres and, given the first-cycle immature nature of the sediments, are 
probably of local origin. Substantial volcanic centres of appropriate age and composition are absent in New Caledonia, and one must speculate that these are now either entirely eroded away or hidden elsewhere in a hinterland (in Cretaceous times) of the Norfolk or Loyalty Ridges and/or northern Lord Howe Rise. Early Triassic diorites and granodiorites, perhaps connected to volcanic centres, do occur on the Dampier Ridge, and southern Norfolk Ridge (McDougall et al. 1994, Mortimer et al. 1998), but pre-Cretaceous rocks are not known from either the Loyalty Ridge or northern Lord Howe Rise. None of these regions appears to have Late Triassic-Jurassic rocks, of appropriate extent or composition, to provide zircon sources for New Caledonia sediments. For the Late Jurassic-Early Cretaceous sediments, the acidic volcanic centres of Whitsunday Islands, Queensland, which might extend north and south along the northern Lord Howe Rise and Marion Plateau, would provide far more suitable zircon sources. In addition, mid-Cretaceous rhyolites are known from the southern Lord Howe Rise (McDougall and Van der Lingen 1994). To provide zircons for the New Caledonia terrane depocentres from adequate sediment sources, we must therefore speculate that offshore island-arc volcanic centres of Late Triassic to Early Cretaceous age, which are now hidden, once existed along the northern Lord Howe Rise and Marion Plateau. In addition these centres might have formed an intermittent barrier to rivers originating in eastern Gondwanaland which supplied the older, continental zircons.

\section{Inherited continental zircon components}

It is notable that the older $(>250 \mathrm{Ma})$, zircons in the New Caledonia sediments are overwhelmingly (>90\%) early Paleozoic and Precambrian (mostly 500-700 Ma). In 
particular, there are few individual zircons in the Middle Permian-Early Triassic, 245$270 \mathrm{Ma}$ (Figs. 4, 5) age range, and none constitute statistically significant age components. This is surprising, because voluminous plutonic (and volcanic) complexes of this age (and also Early Permian-Late Carboniferous) are extensive within the New England Orogen, along 2000 kilometres of the northeastern, present-day, margin of Australia (Veevers 2000). This fold-belt would be have been undergoing uplift and erosion at this time, sufficiently to supply marine depocentres at the Gondwana continental margin at a latitude similar to present-day New Caledonia. This is indeed the case for Permian-Triassic volcaniclastic sedimentary rocks of the Gympie Terrane of southeast Queensland (Table 4), now situated between the main plutonic/volcanic arcs of the New England Orogen and New Caledonia in its present position (Korsch et al., 2008 in press). In addition, the petrological, geochemical, mineralogical, faunal and particularly detrital mineral evidence (Pickard et al. 2000, Adams \& Kelley 1998, Adams et al. 2007), indicate that the depocentres of several New Zealand PermianJurassic, Eastern Province tectonostratigraphic terranes developed at these latitudes (Fig. 6). Their sedimentary rocks always contain substantial proportions of Early Triassic-Late Permian zircons and micas, c. 245-270 Ma. Depocentres such as those of the Gympie Terrane of Australia and the Eastern Province terranes of New Zealand, would thus explain the absence of Late Permian-Early Triassic zircons in New Caledonia rocks, by providing an effective sediment trap inshore of New Caledonia. There is the additional possibility that present-day Zealandia continental fragments such as the Lord Howe Rise, Marion Plateau, and Queensland Plateau might have existed then, and were elevated, to provide an additional barrier. 
However, the early Paleozoic and Precambrian zircon components in New Caledonia sediments clearly indicate major access to older continental sources. The same is true of Late Paleozoic (probable Carboniferous) terrane metasediments of the Shoalwater and Wandilla terranes in eastern Queensland (Table 6, Korsch et al., 2008 in press). In contrast, pre-Carboniferous zircons are rare in the Permian-Triassic rocks of the Gympie Terrane (Table 6). It is possible that Early Paleozoic and Precambrian zircons might have originated locally in basement rocks now hidden under Cenozoic cover on the northern Lord Howe Rise, Marion and Queensland Plateaux, but in the absence of any evidence, this is purely speculative. It is perhaps more realistic to look to more distant, interior sources along the Gondwana margin, where early Paleozoic (470-550 Ma) zircons could clearly originate from Early Ordovician granitoids and CambroOrdovician rhyolites of the Mt Windsor Volcanics in the Charters Towers Province (Veevers 2000). However, the origin of the Precambrian zircons is more problematical; for the major part, they could be recycled from Paleozoic metasediments (CambrianCarboniferous) in the Charters Towers, Broken River and Hodgkinson Provinces of northeastern Queensland. In addition, there are also potential primary igneous sources, mostly late Paleoproterozoic and early Mesoproterozoic metavolcanics and gneisses (1500-1800Ma), in the Georgetown, Coen and Yambo Precambrian inliers of the same region (Blewett et al. 1998). However, no primary igneous sources for the late Mesoproterozoic-early Neoproterozoic (950-1150 Ma) zircons are known.

\section{Comparison of New Caledonia and New Zealand terranes}


Similar to the New Caledonia sandstones, Eastern Province terrane metasediments of New Zealand share the same division between contemporary (probably volcanic) and inherited (probably continental) zircon sources. Like New Caledonia, there is difficulty in locating extensive volcanic sources of appropriate composition. The inherited zircon inputs are quite different in their proportions, and this feature suggests that the two regions occupied different positions at the eastern Australian Gondwanaland margin in Permian to Cretaceous times. Although now distant, New Zealand depocentres were then much closer to the New England Orogen, whilst New Caledonia, now adjacent, was formerly remote from it.

\section{TRIASSIC-JURASSIC COMPARISONS}

Triassic-Jurassic, Teremba Terrane rocks have tectonic associations and faunal assemblages similar to the New Zealand Murihiku Terrane (Campbell 1984, Ballance \& Campbell 1993). However, in the latter, the major to dominant (40-80\%) zircon age components are close to the depositional age, characteristic of an active volcanic margin setting. In the Teremba Terrane however, these youngest zircon groups are usually diminished $(<25 \%)$ and there is instead a substantial component (usually $>50 \%$ ) of inherited early Paleozoic-Precambrian zircons. This latter feature is quite unlike any Permian, Triassic or Jurassic examples from the Murihiku Terrane (Table 5B, MATI4, PIOX5, HURW4 respectively). The proportion of early Paleozoic-Precambrian to Triassic-Permian zircons in the Teremba Terrane samples is particularly high, ratio $>2.0$ (Table 5A), and cannot be matched in any New Zealand terranes, where the ratio is always $<1.0$. The closest comparisons are in the New Zealand Torlesse Terrane, where 
Triassic samples (Table 5B, RBW1 to PUD1) are the most zircon-rich, carry the highest inherited zircon component ( $>40 \%$ ), and the ratio is c. 0.7, e.g. Table 5B, NGQ2. A sole exception to this behaviour occurs in the Akatarawa microterrane (a $1 \mathrm{~km}^{2}$ enclave within the Torlesse Terrane) at a Late Permian locality (Table 5B, TAKA10), where the zircon pattern (with ratio, c. 2.0) resembles that from the Late Triassic, Teremba locality (5). Significantly, the microfaunas in this microterrane are considered of Tethyan type (Hada et al. 1995) i.e. of more northerly, lower-latitude origin than that of surrounding Torlesse rocks. (An attempt to pursue this comparison further was unsuccessful, as several Teremba terrane samples of similar Late Permian age were found to be exceptionally zircon-poor and unfavourable for detrital zircon study).

Like the New Caledonia examples, volcanic sources for contemporary zircon inputs into Triassic or Jurassic depocentres of the New Zealand Eastern Province terranes are rarely seen, and where present they are often very minor. This is surprising, as the coarse, firstcycle, immature nature of the sediments suggests short transport from local sources. For this reason, the terranes are considered 'suspect, i.e far-travelled, and tectonically transported from sediment depocentres formerly much closer to the Australian (or Antarctic) Gondwanaland margin.

\section{CRETACEOUS COMPARISONS}

New Caledonia Cretaceous sedimentary successions have two potential points of comparison with New Zealand: (1) Early Cretaceous rocks form a major part of the Torlesse composite Terrane, as basement accretionary complexes (e.g. Pahau terrane) in eastern North Island and northeastern South Island, and (2) Late Cretaceous successions 
are locally present at the base of widespread Cretaceous-Cenozoic cover rocks throughout New Zealand, and also within the Northland, Mt. Camel, and East Cape allochthons of the North Island (Fig. 6, Table 5B) (Suggate 1978). Similar to New Caledonia counterparts, the Cretaceous Torlesse greywackes (Table 5B, Pahau Terrane section) all carry significant proportions $(>30 \%)$ of early Paleozoic and Precambrian zircons, but in contrast, carry an important additional component ( $>30 \%)$ of TriassicPermian zircons (a distinctive feature of all Eastern Province terrane rocks) that weakens the comparison. This latter problem does not arise in Cretaceous rocks from the Northland, Mt. Camel, and East Cape allochthons (Table 5B, allochthon section), since they have fewer $(<10 \%)$ Triassic-Permian zircons, but in turn, their muchdiminished proportion $(<5 \%)$ of early Paleozoic and Precambrian zircons also weakens any comparison too. Unlike New Caledonia there is better evidence for contemporary magmatism in late Early and Late Cretaceous time. Volcanic centres are widespread in the South Island, with major centres that include acid-intermediate magmatism at Mt Somers, Mt Mandamus and in the Clarence/Awatere river valleys, and minor horizons occur in Otago and north Westland (Suggate 1978), and offshore on the southern Lord Howe Rise (McDougall \& Van der Lingen 1974). Major Mesozoic granitoid complexes of the Separation Point Batholith of Nelson (and its counterpart in Fiordland) and the Paparoa Suite of north Westland (Muir et al. 1994, 1996) almost certainly supplied contemporary volcanic centres, now uplifted and removed. On this basis, the comparison of New Zealand with New Caledonia during the Cretaceous is poor. Whilst having major volcanic/plutonic late Early and Late Cretaceous zircon sources nearby, the New Zealand sediments maintained access to older continental zircon sources, (1) 
by recycling of older zircons from underlying Permian-Triassic and early Paleozoic basement rocks within the New Zealand region, and (2) perhaps more distantly, from primary igneous sources in the southernmost part of the New England Orogen. In contrast the New Caledonia Cretaceous sediments evaded sources within the New England Orogen, yet maintained some access to older zircon sources. The latter might have been recycled from late Early Cretaceous sedimentary rocks (cf. sample NCAL10 of the Central terrane) within New Caledonia, but now largely hidden or eroded away. Prior to $85 \mathrm{Ma}$ (oldest seafloor in the Tasman Sea), during the initiation of rifting in mid-Cretaceous times, the development of the extensive Whitsunday Islands (eastern Queensland) silicic volcanic province, would have provided an important zircon source. This had the additional benefit of proximity to the early Paleozoic and Precambrian provinces of northeastern Queenland. However, it must be recognised that this scenario is much weakened if one accepts a continuation, as suggested by Mortimer et al. (2008), of the New England Orogen beyond of its northernmost onshore occurrence on to the Queensland Plateau. Sediments derived from this sources in this region would then surely contain the Late Permian-Early Triassic zircon components so characteristic of the New England Orogen, but which are mostly absent in New Caledonia.

\section{New Caledonia terranes at the eastern Australia Gondwana margin}

The Late Permian-Late Cretaceous terranes in New Caledonia and New Zealand have a similar tectonic setting in an accretionary prism environment. Terrane sediments in both areas show varying combinations of contemporary, redeposited volcaniclastic and inherited, continental clastic sediment inputs. However their geographic positions 
relative to the Gondwanaland foreland must be quite different, with older PaleozoicPrecambrian zircon sources more apparent in the New Caledonia terranes, at the expense of the Late Permian-Early Triassic sources which dominate the New Zealand terranes. In New Caledonia, whilst the persistent contemporary volcaniclastic sediment sources are probably local, the older zircons sources are almost certainly outside the immediate New Caledonia region. The nearest available plutonic and metamorphic complexes of early Paleozoic-Precambrian age are in northeasternmost Queensland, at a point where the Australian Precambrian craton comes closest to the Pacific margin of Gondwanaland. However, it should be noted that the available age data for the northernmost Queensland Precambrian basement rocks Blewett et al. 1998), are dominantly early Mesoproterozoic, 1500-1600 Ma, rather than the younger Precambrian, 900-1100 Ma, ages more commonly seen in the New Caledonia detrital zircon sets. In this scenario, there is a requirement for long sediment transport, up to 2000 kilometres, via a river/delta/submarine canyon system, from sources that includes Cambrian-Ordovician rocks, such as those of the Broken River Province, and Neo- and Mesoproterozoic rocks, such as those in several adjacent Precambrian inliers. In the Triassic-Jurassic, any such river system must direct such sediments from these sources quite far offshore and then transport it by longshore currents into the New Caledonia region, to avoid capture of zircon sources from the northern New England Orogen (Fig. 6). This latter requirement is especially difficult, as there can be no sediment input into such longshore currents along the 500 kilomtere sector of the northeast margin of the orogen. However, Leitch et al. (2003) have suggested a similar scenario for derivation of late Paleozoic, Shoalwater and Wandilla terrane sediments in eastern Queensland 
from older continental sources in northeastern Queensland. The continental sediment supply must diminish substantially in Cretaceous times, either as a consequence of gradual erosion of the source areas, or the intervention of a sediment trap or barrier e.g. initiation of rift basins or volcanic arcs offshore.

Alternatively, the sediment transport may have been relatively short (c. $200 \mathrm{~km}$ ), into depocentres at the immediate Gondwana margin of northeasternmost Queensland (Fig.6). In Early Cretaceous times, such depocentres would have been be consolidated and tectonically transported southwards, as suspect terranes, by dextral strike-slip, margin-parallel displacement, outboard of the New England Orogen, and into the New Caledonia region. The Triassic-Jurassic terranes transported in this way would gradually approach a hinterland to New Caledonia, comprising local Cretaceous volcanic arcs e.g. Whitsunday Islands, Maryborough Basin, and hence become dominated by their contemporary volcaniclastic sediment inputs. Pickard et al. (2000) and Adams et al. (2007) have suggested this kind of scenario for transport the Late Palezoic-Mesozoic, Torlesse composite terrane of New Zealand from eastern Australia. However, like the New Zealand example, this scenario encounters anomalies, because the relative original positions of the New Caledonia sediment depocentres at the Gondwanaland margin would been the opposite of their final relative terrane positions in New Caledonia. The Boghen terrane, whose sediment depocentre had most 'continental' (inherited) zircons, would now be outboard of the Teremba Terrane, whose sediment depocentre was more local, and had the least 'continental' influence. 


\section{SUMMARY OF CONCLUSIONS}

Geochemical and $\mathrm{Sr}-\mathrm{Nd}$ isotopic characteristics of Mesozoic greywackes in the Teremba and Central Terranes of New Caledonia indicate a uniform offshore, probable subduction-related tectonic environment, with minor continental sediment contribution.

Detrital zircon U-Pb age patterns for sandstones of the Formation á Charbon, and greywackes of the Central and Teremba Terranes indicate local offshore depocentres in an active margin tectonic environment, with substantial contemporaneous volcaniclastic sediment supplies in Late Triassic, Late Jurassic and particularly mid-Cretaceous times. In the Teremba Terrane, an older, inherited zircon component from continental sources is usually (but not always) important, most commonly Precambrian and Cambrian in age. In contrast, the Boghen terrane sandstones have much diminished contemporary (Late Jurassic) zircon contributions, and a major contribution ( $>50 \%)$ of Early Paleozoic and Precambrian zircons. In all terranes there are few late Paleozoic-early Mesozoic zircons, especially in the age range Late Permian to Early Triassic, which latter feature would thus probably exclude sediment sources from along the adjacent Gondwana margin in the northern New England Orogen. It is concluded that the primary contemporary zircon sources must lie hidden, or are now eroded, somewhere in the New Caledonia hinterland, on the Loyalty and Norfolk Ridges, or northern Lord Howe Rise and Dampier Ridge, or Marion and Queensland Plateaux. A degree of local zircon reworking, from Triassic into Jurassic, and Jurassic into Cretaceous sediments is possible. The continent-derived zircons probably have primary, and/or reworked detrital sources in Paleozoic and Precambrian rocks of northeast Queensland. Here there are several Proterozoic igneous/metamorphic inliers and Paleozoic sedimentary 
successions of the Charters Towers, Broken River and Hodgkinson Provinces, which are close to the Gondwana margin and beyond the northernmost extremity of the New England Orogen. The sediment supplied from these areas must have been transported southwards by longshore currents, outboard of the orogen, to depocentres in New Caledonia. Alternatively, the depocentres themselves may have originated closer to source at the contemporary Gondwana margin, and then transported tectonically southwards, as suspect terranes in Early Cretaceous times, to their present New Caledonia position. This latter scenario resembles that suggested for New Zealand Permian-Cretaceous sediment depocentres that developed close the Gondwana margin of northeastern Australia.

\section{ACKNOWLEDGMENTS}

We thank Hamish Campbell, Pierre Maurizot and Nick Mortimer for sharing their extensive knowledge of the geology of New Caledonia, New Zealand and the surrounding ocean regions. Norman Pearson and Suzy Elhlou also provided skilled technical assistance at the GEMOC Laboratory, Macquarie University, Sydney. Funding was provided by a France-New Zealand Collaborative Research Programme project: Geological Correlations between New Caledonia and New Zealand, and the New Zealand Foundation for Research Science \& Technology (Mineral Wealth of New Zealand Programme). John Bradshaw and Sebastian Meffre are thanked for their substantial and comprehensive reviews.

\section{REFERENCES}


AdAms, C. J. \& Kelley, S. 1998. Provenance of Permo-Triassic and Ordovician metagreywacke terranes in New Zealand: evidence from ${ }^{40} \mathrm{Ar} /{ }^{39} \mathrm{Ar}$ dating of detrital micas. Geological Society of America Bulletin 110, 422-432.

Adams, C. J., Barley, M. E., MaAs, R., \& Doyle, M. G. 2002. Provenance of Permian-Triassic volcaniclastic sedimentary terranes in New Zealand: evidence from their radiogenic isotope characteristics and detrital mineral age patterns. New Zealand Journal of Geology and Geophysics 45, 221-242.

AdAms, C. J., CAMPBell, H. J., \& GRIFFIN, W. R. 2007. Provenance Comparisons of Permian to Jurassic Tectonostratigraphic Terranes in New Zealand: Perspectives from detrital zircon age patterns. Geological Magazine 144, 701-729.

Aitchison, J. C., Clarke, G. L., Cluzel, D., \& MefFre, S. 1995. Eocene arc-continent collision in New Caledonia and implications for regional southwest Pacific tectonic evolution, Geology, 23, 161164

Aitchison, J. C., Ireland, T. R., Cluzel, D., Davis, A. M., \& MefFre, S. 1998. Regional implications of U/Pb SHRIMP age constraints on the tectonic evolution of New Caledonia. Tectonophysics 299, 333-343.

Ali, J.R. \& Aitchison, J.C. 2002. Paleomagnetic-tectonic study of the New Caledonia Koh Ophiolite and the mid-Eocene obduction of the Poya Terrna. New Zealand Journal of Geology \& Geophysics 45, 313-322.

Andersen, T. 2002. Correction of common $\mathrm{Pb}$ in U-Pb analyses that do not report ${ }^{204} \mathrm{~Pb}$. Chemical Geology (Isotope Geoscience) 192 , 59-79.

ANDERSEN, T. 2005. Detrital zircons as tracers of sedimentary provenance: limiting conditions from statistics and numerical simulation. Chemical Geology (Isotope Geoscience) 216, 249-270.

Aronson, J.L., \& Tilton, G. R. 1971. Probable Precambrian detrital zircons in New Caledonia and Southwest Pacific continental structure. Geological Society of America Bulletin 82, 3449-3456.

Ballance, P. F., \& CAmpBell, J. D. 1993. The Murihiku arc-related basin of New Zealand (TriassicJurassic). In Ballance, P.F. ed. South Pacific Sedimentary Basins, Sedimentary Basins of the World. Elsevier, Amsterdam, 21-33. 
Bishop, D. G., Bradshaw, J. D. \& Landis, C. A. 1985. Provisional terrane map of South Island, New Zealand. In Howell, D.G. (ed) Tectonostratigraphic Terranes, Circum - Pacific Council for Energy and Mineral Resources Earth Science Series No. 1, Houston, Texas, 515-521.

Black, P. M. 1984. The 'Waipapa Terrane', North Island, New Zealand: subdivision and correlation. Geoscience Reports of Shizuoka University 20, 55-62.

Blake, M. C., Brothers, R. N., \& Lanphere, M. A. 1977. Radiometric ages of blueschists in New Caledonia. In International Symposium on Geodynamics in the South West Pacific. Nouméa, 1976, Edition Technip, Paris, 276-282.

Blewett, R.S., Black, L.P., S-S., Sun., Knutson, J., Hutton, L.J., Bain, J.H.C. 1998. U-Pb zircon and Sm-Nd geochronology of the Mesoporoterozoic of North Queensland: implications for a Rodinian connection with the Belt supergroup of North America. Precambrian Research 89, 101127.

CampBell, H. J. 1984. Petrography and metamorphism of the Téremba Group (Permian to Lower Triassic) and the Baie de St. Vincent Group (Upper Triassic to Lower Jurassic), New Caledonia. Journal of the Royal Society of New Zealand, 14, 335-348.

Campbell, H. J., Grant-Mackie, J. A., \& Paris, J. P. 1985. Geology of the Moindou-Téremba area, New Caledonia; stratigraphy and structure of the Teremba Group (Permian-Lower Triassic) and Baie de St. Vincent Group (Upper Triassic-Lower Triassic). Géologie de France, BRGM, 1, 1936.

Cawood, P.A., Nemchin, A.A., Leverenz, A., Saeed, A., Ballance, P.F. U/Pb dating of detrital zircons : Implications for the provenance record of Gondwana margin terranes. Geological Society of America Bulletion 111, 1107-1119.

Cluzel, D., \& Meffre, S. 2002. L'unité de la Boghen (Nouvelle-Calédonie, Pacifique sud-ouest): un complexe d'accrétion jurassique. Données radiochronologiques préliminaires U-Pb sur les zircons détritiques. C.R. Géosciences. 334, 867-874.

Coombs, D.S., Landis, C.A., Norris, R.J., Sinton, J.M., Borns, D.J., Craw, D. 1976. The Dun Mountain Ophiolite, New Zealand, its tectonic setting, constitution, and origin, with special reference to the southern portion. American Journal of Science 276, 561-603. 
COOPER, R. A. (COMPILER) 2005. A New Zealand Geological Timescale. Institute of Geological \& Nuclear Sciences Monograph 22.

Gaina C., MÜller D.R., Royer J.Y., Stock J., HARdebeck J., Symonds P., 1998. The tectonic history of the Tasman sea: a puzzle with 13 pieces. Journal of Geophysical Research, 10, 312,413$12,433$.

Grant-Mackie, J. A., Paris, J. P. FreneiX, S., \& Campbell, J. D. 1977. Advances in correlation of Mesozoic sequences in New Zealand and New Caledonia. 25 ${ }^{\text {th }}$ International Geological Congress, Abstracts, 1, 268-269.

GuÉRANGÉ, B., LILlE, R., \& LOZES, J. 1975. Etude géologique des terrains anté-Oligocène de la chaine centrale néo-calédonienne; stratigraphie, régime de sédimentation, évolution structurale et métamorphisme. Bulletin BRGM, Fr. Section 4 2, 121-137.

Govindaraju K. \& Mevelle G. 1987. Fully automated dissolution and separation methods for inductively coupled plasma atomic emission spectrometry rock analysis. Application to the determination of rare earth elements. Journal of Analytical Atomic Spectrometry 2, 615-621.

HADA, S., LANDIS, C.A. 1995. Te Akatarawa Formation - an exotic oceanic-continental margin terrane within the Torlesse-Haast Schist transition zone. New Zealand Journal of Geology and Geophysics 38, 349-359.

HALL R., 2002. Cenozoic geological and plate tectonic evolution of SE Asia and the SW Pacific: computer-based reconstructions, model and animations. J. of Asian Earth Sci., 20, 353-431.

IRELAND, T.R. 1992. Crustal evolution of New Zealand: Evidence fromage distributions of zircons in Western Province paragneisses and Torlesse greywacke. Geochimica et Cosmochimica Acta 56, 911-920.

Jackson, S. E., Pearson, N. J., Griffin, W. L., \& Belousava, E. A. 2004. The application of laser abalation-inductively coupled plasma-mass spectrometry (LA-ICP-MS) to in situ U-Pb zircon geochronology. Chemical Geology, 211, 47-69.

JaCOBSEn S. B. \& WASSERburg J. G. 1980. Sm-Nd isotopic evolution of chondrites. Earth and Planetary Science Letters 50, 139-55. 
Kimbrough, D. L., Mattinson, J. M., Coombs, D. S., Landis, C. A., \& Johnston, M. R. 1992. Uranium-lead ages from the Dun Mountain Ophiolite Belt and Brook Street Terranes, South Island, New Zealand. Geological Society of America Bulletin 104, 429-443.

Korsch. R.J., AdAms, C.J., Black, L.P., Foster, D.A., Fraser, G.L., C. Foudoulis, C., GRIFfin, W.J., \& MURRAY, C.G. 2008 in press. Geochronology and provenance of the accretionary wedge at the Late Paleozoic convergent margin of eastern Gondwanaland, Australia.

landis, C.A., Campbell, H.J., Aslund, T., Cawood, P.A., Pillai, D.D.L., Raine, J.I., Willsman, A. 1999. Permian-Jurassic strata at Productus Creek, Southland, New Zealand: implications for terrane dynamics at the eastern Gondwanaland margin. New Zealand Journal of Geology and Geophysics 42, 255-278.

Leitch, E.C., Fergusson, C.L. \& Henderson, R.A., 2003. Arc to craton provenance switching in a Late Palaeozoic subduct ion complex, Wandilla and Shoalwater terranes, New England Fold Belt, eastern Australia. Australian Journal of Earth Sciences 50, 919-929.

MCDougall, I., \& VAN DeR Lingen, G. J. 1974. Age of the rhyolites of the Lord Howe Rise and the evolution of the Southwest Pacific Ocean. Earth and Planetary Science Letters 21, 117-126.

McDougall, I. Maboko, M.A.H, Symonds, P.A., McCulloch, M.T., Williams, I.S., \& Kudrass, H.R. 1994. Dampier Ridge, Tasman Sea, as a stranded continental fragment. Australian Journal of Earth Sciences 41, 395-406.

MackinNON, T. C. 1983. Origin of the Torlesse Terrane and coeval rocks, South Island, New Zealand. Geological Society of America Bulletin 94, 967-985.

MEFFrE, S., 1995. The developpement of arc-related ophiolites and sedimentary sequences in New Caledonia. PhD Thesis, University of Sydney, 236 p.

Meffre, S., Aitchison, J. C., \& Crawford, A. J. 1996. Geochemical stratigraphy of boninites and tholeiites from the Permo-Triassic Koh Ophiolite, New Caledonia. Tectonics 15, 67-83.

Mortimer, N., Herzer, R.H., Ganz, P.B., Parkinson, D.L., \& Seward, D. 1998. Basement geology from Three Kings Ridge to West Norfolk Ridge, southwest Pacific Ocean : evidence from petrology, geochemistry and isotopic dating of dredge samples. Marine Geology 148, 135-162. 
Mortimer, N., Tulloch, A. J., Gans, P., Calvert \& Walker, N. 1999 Geology and thermochronometry of the east edge of the Median Tectonic Batholith (Median Tectonic Zone): a new perspective on Permian to Cretaceous crustal growth of New Zealand. Island Arc 8, 404425.

Mortimer, N., HaufF, F., \& CAlvert, A. T. 2008. Continuation of the New England Orogen, Australia beneath the Queensland Plateau and Lord Howe Rise. Australian Journal of Earth Sciences 55, 195-209.

Muir, R.J., Ireland, T.R., Weaver, S.D., Bradshaw, J.D. 1994. Ion-microprobe U-Pb zircon dating of granitic magmatism in the Western Province of South Island, New Zealand and correlations with Australia and Antarctica. Chemical Geology (Isotope Geosciences Section) 113, 171-189.

Muir, R.J., Ireland, T.R., Weaver, S.D., Waight, J.D., Jongens, R., Eby, G.N. 1997. Shrimp U-Pb geochronology of Cretaceous magmatism in northwest Nelson-westland, South Island, New Zealand. New Zealand Journal of Geology and Geophysics 40, 453-63.

PARIS, J. P. 1981. La Géologie de la Nouvelle-Calédonie, un essai de synthèse. Mémoire BRGM, 133, 250pp.

PeARCE, J. A., 1982. Trace element characteristics of lavas from destructive plate margins. In Thorpe R. S. ed. Andesites, Wiley, Winchester, 525-548.

Pickard, A. L., Adams, C. J., \& Barley, M. E. 2000. Australian provenances for Upper Permian to Cretaceous rocks forming accretionary complexes on the New Zealand sector of the Gondwanaland margin. Australian Journal of Earth Sciences 47, 987-100.

Pin C. \& SAntos ZALduegui J. F. 1997. Sequential separation of light rare-earth elements, thorium and uranium, by miniaturized extraction chromatography: Application to isotopic analyses of silicate rocks. Analytica Chimica Acta 339, 79-89.

RoSER, B. P., \& KORSCH, R. J. 1988. Provenance signatures of sandstone-mudstone suites determined using discriminant function analysis of major element data. Chemical Geology 67, 119-139.

Roser, B. P. \& KoRSCH, R. J. 1999. Geochemical characterisation, evolution and source of a Mesozoic accretionary wedge, the Torlesse terrane, New Zealand. Geological Magazine 136, 493-512. 


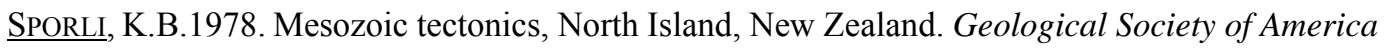
Bulletin 89, 415-425.

Sivell, W.J. \& MCCulloch, M.T. 2000. Reassessment of the origin of the Dun Mountain Ophiolite, New Zealand: Nd-isotopic and geochemical evolution of magma suites. New Zealand Journal of Geology \& Geophysics 43, 133-146.

SUGGATE, R.P. (ED.) 1978. The Geology of New Zealand. Wellington, Government printer, 343p.

Sun, S. S. \& MCDONOUGH, W. I., 1989. Chemical and isotopic systematics of oceanic basalts: implications for mantle composition and processes. In: A.D. Saunders and M.D. Norry, eds Magmatism in the Ocean Basins. Geological Society of London Special Publication 42, 313 345.

SUTHERLAND R. 1999. Basement geology and tectonic development of the greater New Zealand region: an interpretation from regional magnetic data. Tectonophysics, 308, 341-362.

TURnBULL, I.M. 1979. Stratigraphy and sedimentology of the Caples terrane of the Thomson Mountains, northern Southland, New Zealand. New Zealand Journal of Geology and Geophysics 22, 555-574.

VeEVERS, J. J. ED. 2000. Billion-year earth history of Australia and neighbours in Gondwanaland. Gemoc Press, Sydney, 388p.

Wandres, A. M., Bradshaw, J. D., Weaver, S., MaAs, R., Ireland, T. R, \& Eby, N. 2004a. Provenance analysis using conglomerate clast lithologies: a case study from the Pahau terrane of New Zealand. Sedimentology 167, 57-89.

Wandres, A. M., Bradshaw, J. D., Weaver, S., MaAs, R., Ireland, T. R., \& Eby, N. 2004B. Provenance of the sedimentary Rakaia sub-terrane, South Island, New Zealand: the use of igneous clast compositions to define the source. Sedimentology 168, 193-226.

Williams, H.A., Cassidy, J., Corinne, A., Locke, K. \& Spörli, B. 2006. Delineation of a large ultramafic massif embedded within a major SW Pacific suture using gravity methods. Tectonophysics 424, 119-133.

\section{FIGURE CAPTIONS:}


Figure 1a: Geological map of New Caledonia basement terranes and U-Pb geochronology sampling localities.

Figure 1b: New Caledonia in the Southwest Pacific region in Cretaceous times.

Figure 2a: Expanded REE-trace elements spider-diagram normalised to the average MORB for selected New Caledonia terrane greywackes (normalising values are from Sun \& McDonough, 1989)._Labelled patterns refer to sediments which have slightly negative $\varepsilon N d$ (see Fig. 3 and Table 2)

Figure 2b: Expanded REE-trace elements spider-diagram normalised to the average MORB for selected Teremba terrane volcanic rocks (normalising values are from Sun \& McDonough, 1989)

Figure 3: Sr-Nd evolution diagram for selected New Caledonia terrane greywackes showing remarkably constant isotopic ratios through time and the quasi-absence of contamination. Arrows with interrogation marks refer to either the array resulting from magma contamination by pelagic sediments (moderately negative $\varepsilon \mathrm{Nd}$, high $\varepsilon \mathrm{Sr}$ ); or, alternatively contamination by lower continental crust (negative $\varepsilon \mathrm{Nd}$, slightly positive $\varepsilon \mathrm{Sr})$.

Figure 4: Combined histogram and probability density diagrams of detrital zircon age data from nine greywackes from New Caledonia terranes, Statistically significant age components (expressed in millions of years) are shown in bold italics. Ages $>600 \mathrm{Ma}$ are stacked at right side. Ages $<1000 \mathrm{Ma}$ are ${ }^{238} \mathrm{U} /{ }^{206} \mathrm{~Pb}$ data, ages $>1000 \mathrm{Ma}$ are ${ }^{207} \mathrm{~Pb} /{ }^{206} \mathrm{~Pb}$ data.

Figure 5: A summary of detrital zircon ${ }^{238} \mathrm{U} /{ }^{206} \mathrm{~Pb}$ age component data from the cumulative probability diagrams (Fig. 4) of nine greywackes from New Caledonia terranes. These component age data are stacked from top to bottom in ascending biostratigraphic age order (where known), or estimated maximum and minimum stratigraphic ages derived respectively from youngest detrital zircon age components, and metamorphic ages. The height of each databox indicates the component's proportion of total (see \% scale bar at right) and the width is the component age error (at 95\% confidence limits. The dot-dash line is the stratigraphic age limit - all zircon data should be older than this.

Figure 6: Configuration of Eastern Gondwanaland during the Mesozoic (modified from Gaina et al. 1998; Sutherland 1999; and Hall 200), showing possible position of sources of New Caledonia terrane sediments, suggested depocentres, and their final destinations for terrane assembly. Black arrows show generally local transport of sediments derived from contemporary volcanic arc sources. Light grey 
arrows show more distant transport of older, continent-derived sediments from the Gondwana margin. Two scenarios are suggested: in Fig. 6A, the continent derived-sediments are supplied to on long-shore river systems to depocentres in New Caledonia and in Fig. 6B, the continent-derived sediments are supplied to more local depocentres at the Gondwana margin, which are then tectonically transported in Early Cretaceous times, as suspect terranes, to a final destination in New Caledonia. The positions of equivalent New Zealand depocentres and terranes are taken from Adams et al. (2007).

\section{LIST OF TABLES:}

Table 1a: Major and trace element data for New Caledonia Teremba and Central terrane greywackes.

Table 1b: Major and trace element data for New Caledonia Teremba volcanic rocks

Table 2: Sr-Nd isotopic data for New Caledonia Teremba and Central terrane greywackes.

Table 3: Sample list for U-Pb zircon geochronology

Table 4: Summary of statistically significant age components in detrital zircon age patterns in New Caledonia terrane metasediments (see Fig. 4).

Table 5: New Caledonia detrital zircon ages (5A) summarised in geological periods, and compared with correlative New Zealand data (5B).

Table 6: New Caledonia detrital zircon ages summarised in geological periods (6A), and compared with correlative Australian data (6B).

\section{Appendix I: Technical details}

\section{GEOCHEMICAL AND ISOTOPIC ANALYSES}

Whole rock geochemical analysis of representative volcanic rocks and greywacke samples are by ICP-AES for major elements and ICP-MS for REE and other trace elements (Table 1) at the Service d'Analyse des Roches et des Minéraux of Vandeuvre (Centre National de la Recherche Scientifique, France), using the methods of 
Govindaraju and Mevelle (1987). To avoid pollution by biogenic carbonate without affecting other mineral phases, all the greywackes samples have been leached with acetic acid prior to isotope analysis. $\mathrm{Nd}$ and $\mathrm{Sr}$ isotopic analyses (Table 2) were determined at the Clermont-Ferrand isotope laboratory by thermal ionization mass spectroscopy (TIMS) using a VG54E instrument in dynamic double collection mode and corrected for mass fractionation by normalization to ${ }^{86} \mathrm{Sr} /{ }^{88} \mathrm{Sr}=0.1194$ and ${ }^{146} \mathrm{Nd} /{ }^{144} \mathrm{Nd}=0.7219$. The $\mathrm{Sr}-\mathrm{Nd}$ sample decomposition and chemical separation procedures are those of Pin and Santos Zalduegui (1997). Sr and Nd isotopic ratios were corrected for radiogenic decay according to their assumed stratigraphic age. The concentrations of $\mathrm{Sm}, \mathrm{Nd}, \mathrm{Rb}$ and $\mathrm{Sr}$ are given in $\mu \mathrm{g} / \mathrm{g}$, and the precision of ${ }^{147} \mathrm{Sm} /{ }^{144} \mathrm{Nd}$ and ${ }^{87} \mathrm{Rb} /{ }^{86} \mathrm{Sr}$ measurements are $0.2 \%$ and $2 \%$, respectively, at the $95 \%$ confidence level. The ${ }^{143} \mathrm{Nd} /{ }^{144} \mathrm{Nd}$ ratio measured for the La Jolla isotopic standard during the period of analysis gave a mean value of $0.511849\left(\mathrm{SD}=8 \times 10^{-6}, n=70\right)$. The $\varepsilon \mathrm{Nd}_{\mathrm{i}}$ is the initial ${ }^{143} \mathrm{Nd} /{ }^{144} \mathrm{Nd}$ expressed as a fractional deviation in parts per $10^{4}$ from the contemporaneous value of a chondritic (bulk earth) reservoir with present-day ${ }^{143} \mathrm{Nd} /{ }^{144} \mathrm{Nd}=0.512638$ and ${ }^{147} \mathrm{Sm} /{ }^{144} \mathrm{Nd}=0.1966$ (Jacobsen \& Wasserburg 1980). ${ }^{87} \mathrm{Sr} /{ }^{86} \mathrm{Sr}$ ratios were normalized to ${ }^{86} \mathrm{Sr} /{ }^{88} \mathrm{Sr}=0.1194$, with an uncertainty equal to or better than \pm 0.00004 (two standard errors on the mean). The ${ }^{87} \mathrm{Sr} /{ }^{86} \mathrm{Sr}$ ratio measured for the National Institute of Standards and Technology, Standard Reference Material (NIST - SRM) 987 during the period of analysis gave a mean value of $0.71023\left(\mathrm{SD}=2.7 \times 10^{-}\right.$ $\left.{ }^{5}, n=29\right)$.

\section{DETRITAL ZIRCON DATING}


Detrital zircon dating was done at the ARC Key Centre for Geochemical Evolution and Metallogeny of Continents (GEMOC), Macquarie University, Sydney, Australia. Eight samples for detrital zircon studies were chosen from representative collections taken at stratigraphic horizons where coarse-medium greywacke and sandstone predominate, and preferably with established biostratigraphic age control (Table 3). Since these localities are in lower metamorphic grades (typically zeolite to lower pumpellyite-actinolite mineral facies), they are essentially unfoliated rocks and free of metamorphic zircon.

To minimise sample handling for zircon recovery, a $1 \mathrm{~kg}$ sample was collected at the field outcrop as $5 \mathrm{~mm}$-size gravel, removing all weathered rinds, blemishes, inclusions and joint faces. This enabled direct crushing in a tungsten carbide swingmill 2-3 times, for 5-10 seconds, sieving at each stage through a single, 250 micron mesh sieve. The sieved material was washed and decanted several times in water, to remove mud-size fractions, thus retaining a 200-300 g sample in a $\sim 30-250$ micron size range, which was then dried. A heavy mineral concentrate was obtained from a $100 \mathrm{~g}$ portion in sodium polytungstate liquid, adjusted to a specific gravity of 2.95-2.98, from which about 500 zircon grains were then hand-picked as randomly as possible, i.e. taking all grains within a $1 \mathrm{~mm}$ microscope stage field of view. Of these, 50-100 grains were mounted in resin to be polished for LA-ICPMS (laser-ablation inductively-coupled plasma-source mass spectrometry) analysis.

Analytical protocols relating to ablation procedures, mass spectrometric analysis and data treatment are discussed in detail in Jackson et al. (2004). These authors' preferred procedures were followed in this work, using a Merchantek pulsed Nd-YAG laser, frequency-quintupled to operate at $213 \mathrm{~nm}$, and an Agilent 7500S ICPMS instrument. 
In all cases, the ablated spot size was in the range 30-40 microns, with the ablation time about 60 seconds, preceded by 60 seconds background measurement, and followed by 60-120 seconds washout. Groups of 10-12 zircon sample grain analyses were preceded and followed by duplicate analyses of firstly, the in-house zircon standard GJ1, and secondly, by 1-2 analyses each of the international zircon standards, MT-1 and 91500. The GLITTER data interpretation software package (www.els.mq.edu.au/GEMOC/) enabled analysis of $\mathrm{U}, \mathrm{Pb}$ and Th absolute count rates, and all relevant isotopic ratios, during the run cycle, and the elimination of unstable beam intervals, and rejection of data where zircon core regions were inadvertently encountered.

Using the laser spot size of 30-40 microns enabled age measurements to be made adjacent to crystal margins, rather than cores, and preferably, close to crystal terminations (as defined by two crystal edges). Isotopic data were continually monitored during ablation to check that zircon cores were not being intersected. Efficient use of the instrument time dictated that strongly unimodal patterns were investigated only to analysis totals of $\mathrm{N}=33-50$, bimodal patterns to $\mathrm{N}=50-70$, and strongly polymodal patterns to $\mathrm{N}=100$ (N.B. throughout this work ' $\mathrm{N}$ ' and ' $\mathrm{n}$ ' refer to dataset totals and subgroups respectively). This allowed significant age groups (n) comprising $>5 \%$ of the total to be revealed by three or more analyses (Andersen 2005).

Full ${ }^{207} \mathrm{~Pb} /{ }^{206} \mathrm{~Pb},{ }^{206} \mathrm{~Pb} /{ }^{238} \mathrm{U},{ }^{207} \mathrm{~Pb} /{ }^{235} \mathrm{U}$, and ${ }^{208} \mathrm{~Pb} /{ }^{232} \mathrm{Th}$ age data (and 1 standard errors) are listed in the Appendix Table 1. All ages used here are ${ }^{206} \mathrm{~Pb} /{ }^{238} \mathrm{U}$ zircon ages where $<1000 \mathrm{Ma}$, and ${ }^{207} \mathrm{~Pb} /{ }^{206} \mathrm{~Pb}$ ages where $>1000 \mathrm{Ma}$. A small minority of the analyses have common $\mathrm{Pb}$ corrections (using protocols of Andersen 2002). The age datasets are 
shown in Fig. 4 as combined probability density/histogram diagrams (using a common $\mathrm{X}$-axis format, 0-600 Ma, with ages $>600 \mathrm{Ma}$ stacked at right). Age groupings in probability density plots of the zircon age sets (Fig. 4) were determined by visual inspection and using deconvolution (and weighted average) algorithms in the ISOPLOT-Ex (version 3.0) software (kindly provided by K. Ludwig, United States Geological Survey). The treatment of these age datasets was constrained by two conservative criteria imposed to reveal only statistically significant age groups viz. those with $\mathrm{n}>3$ concordant ${ }^{206} \mathrm{~Pb} /{ }^{238} \mathrm{U}$ v. ${ }^{207} \mathrm{~Pb} /{ }^{235} \mathrm{U}$ ages, and which comprise $>4 \%$ of the total population (N). This was relaxed to $\mathrm{n} \geq 3$ for datasets with $\mathrm{N}<30$. Following Andersen (2005), the age groups are discussed using five categories: 'dominant' $>80 \%$, 'large' $50-79 \%$, 'major' $20-49 \%$, 'minor' $5-19 \%$, and 'accessory' $<5 \%$, of the total. A summary of the statistically significant component ages and errors, their number (n) and proportion (as \%) of the total (N), is given in Table 4 .

Detrital zircon age data for other previously-published and unpublished studies are collated in Tables 5 and 6, and presented with the present New Caledonia datasets. In these tables, all zircon age data are divided into selected geological periods. The New Zealand timescale used here is that of Cooper (2005).

Suggested Running Title: New Caledonia terranes.

Version: NCAL08text March 2009

(6771 words) 


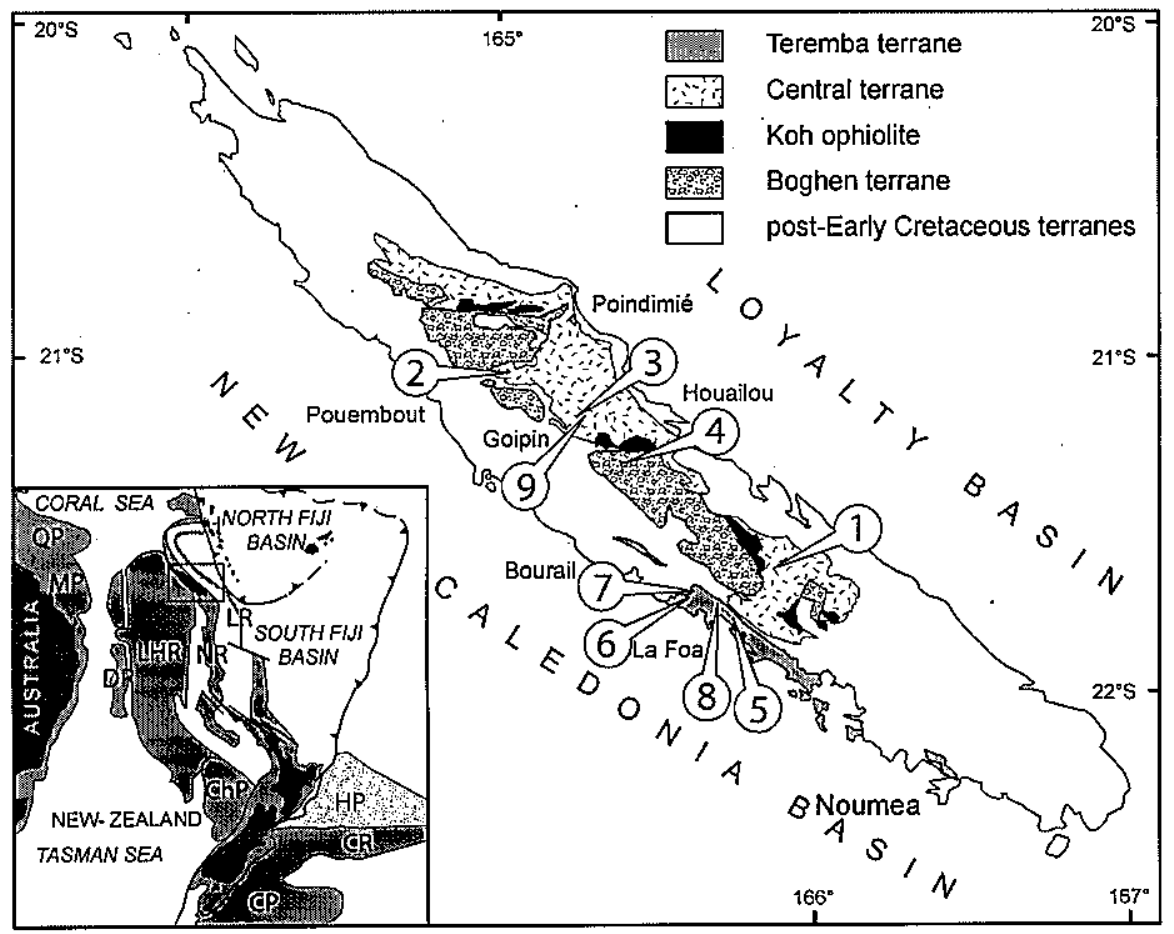



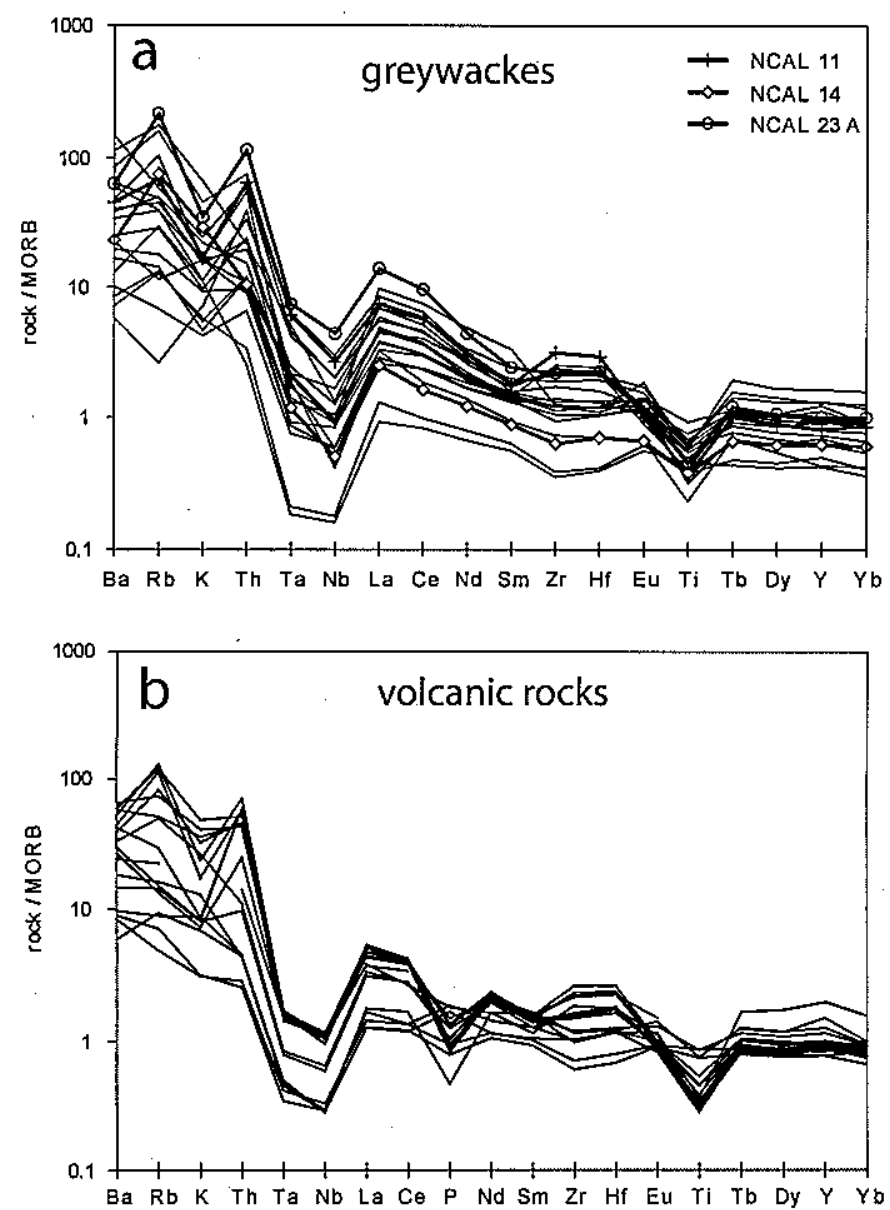


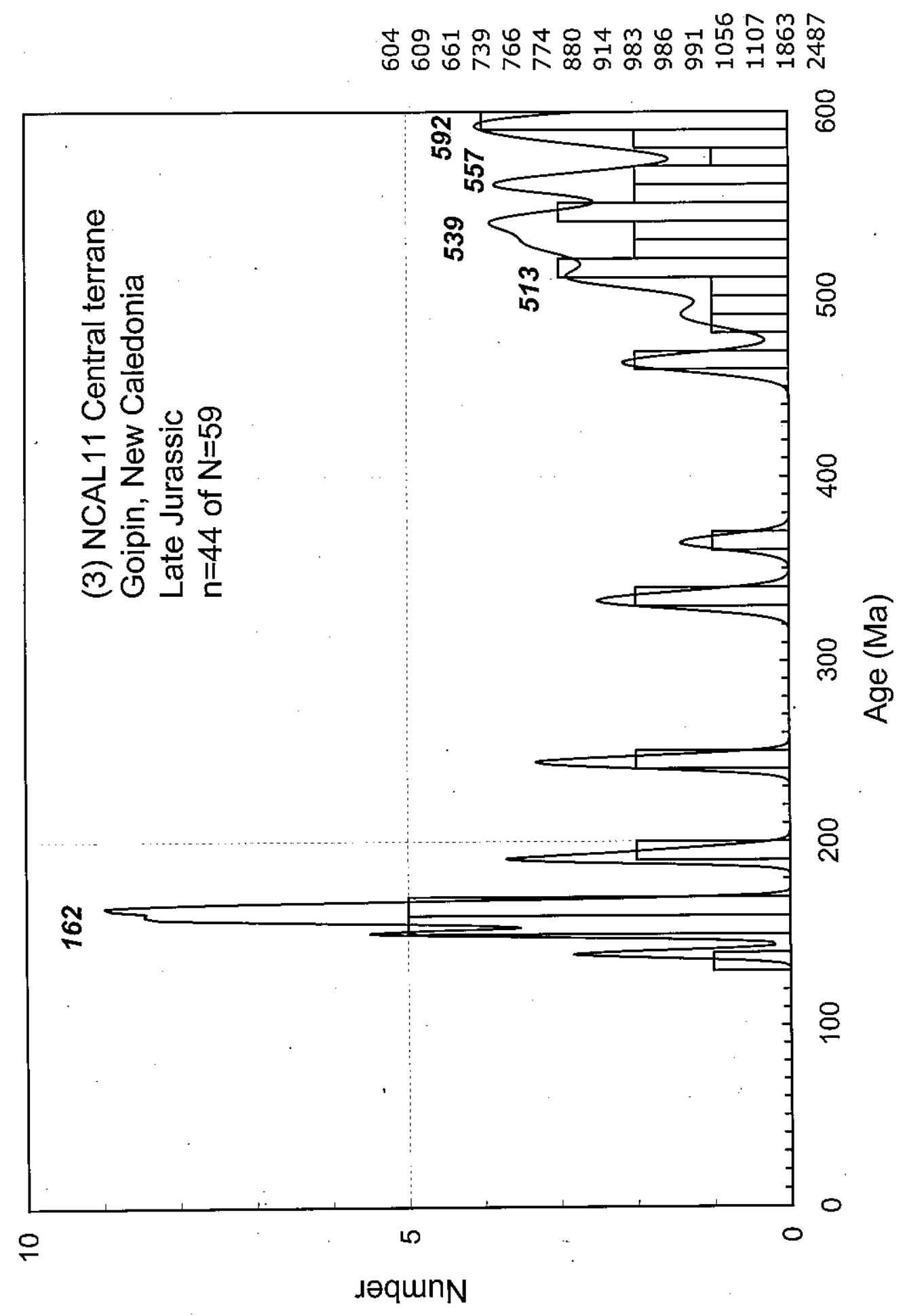




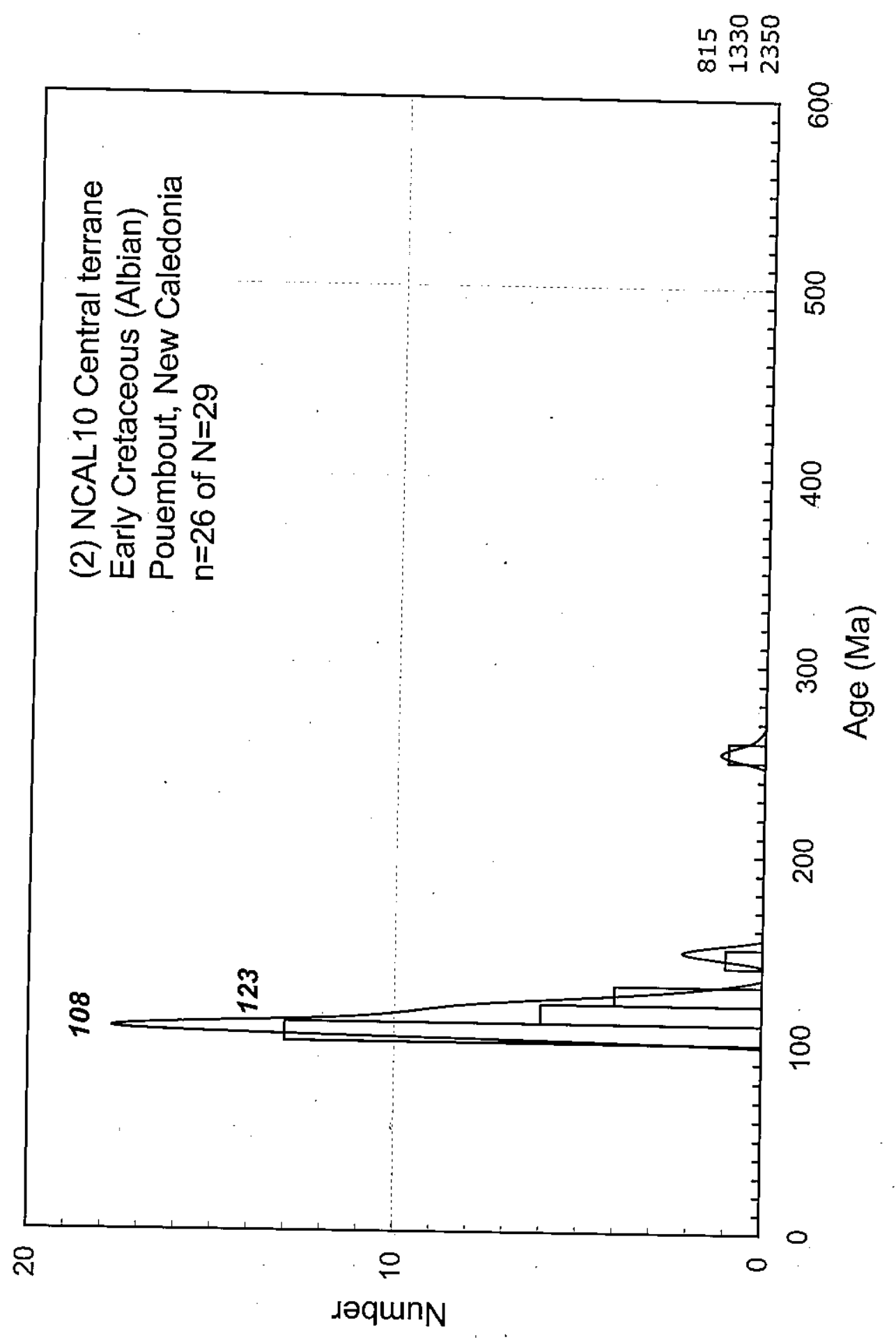




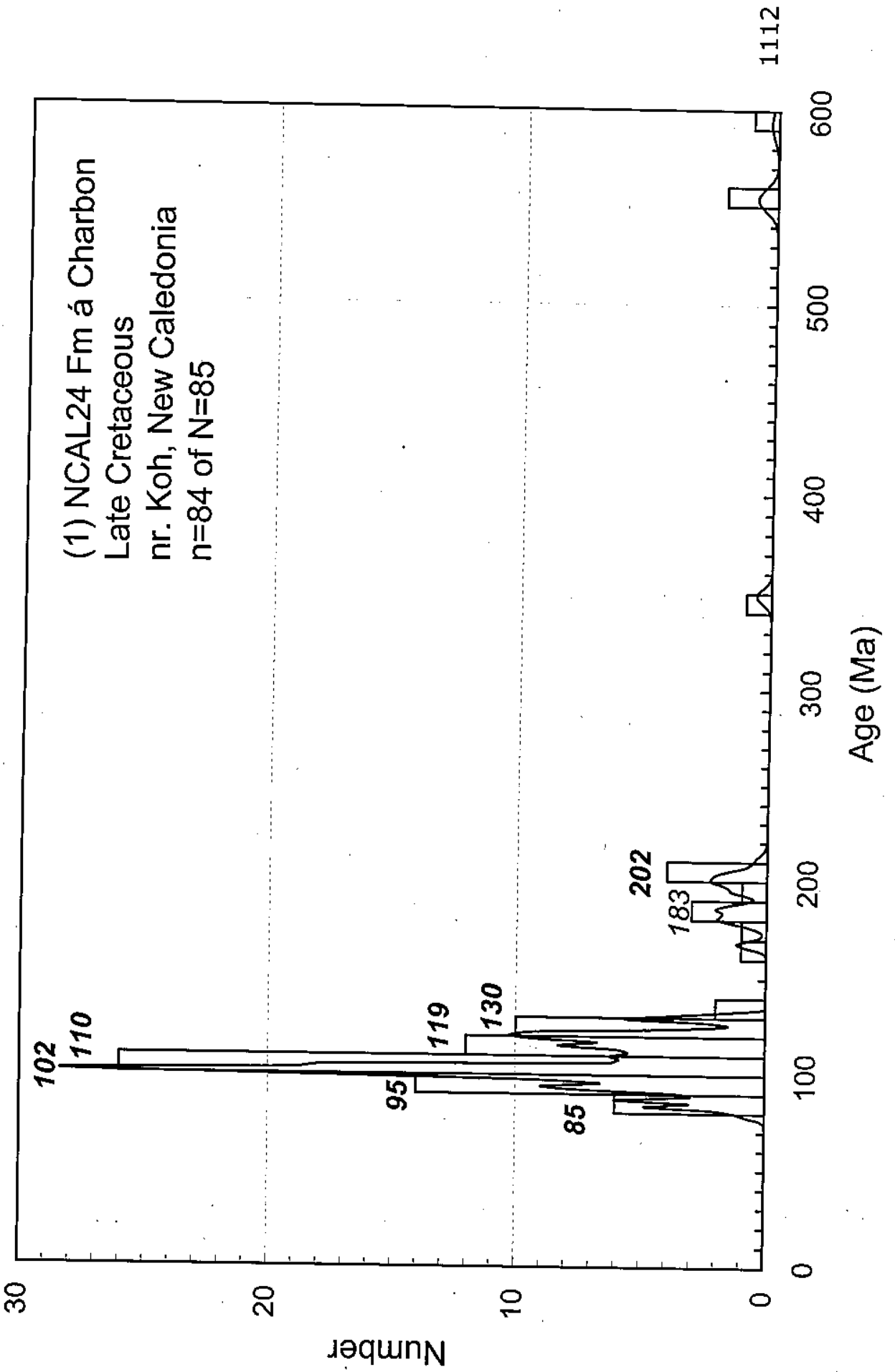




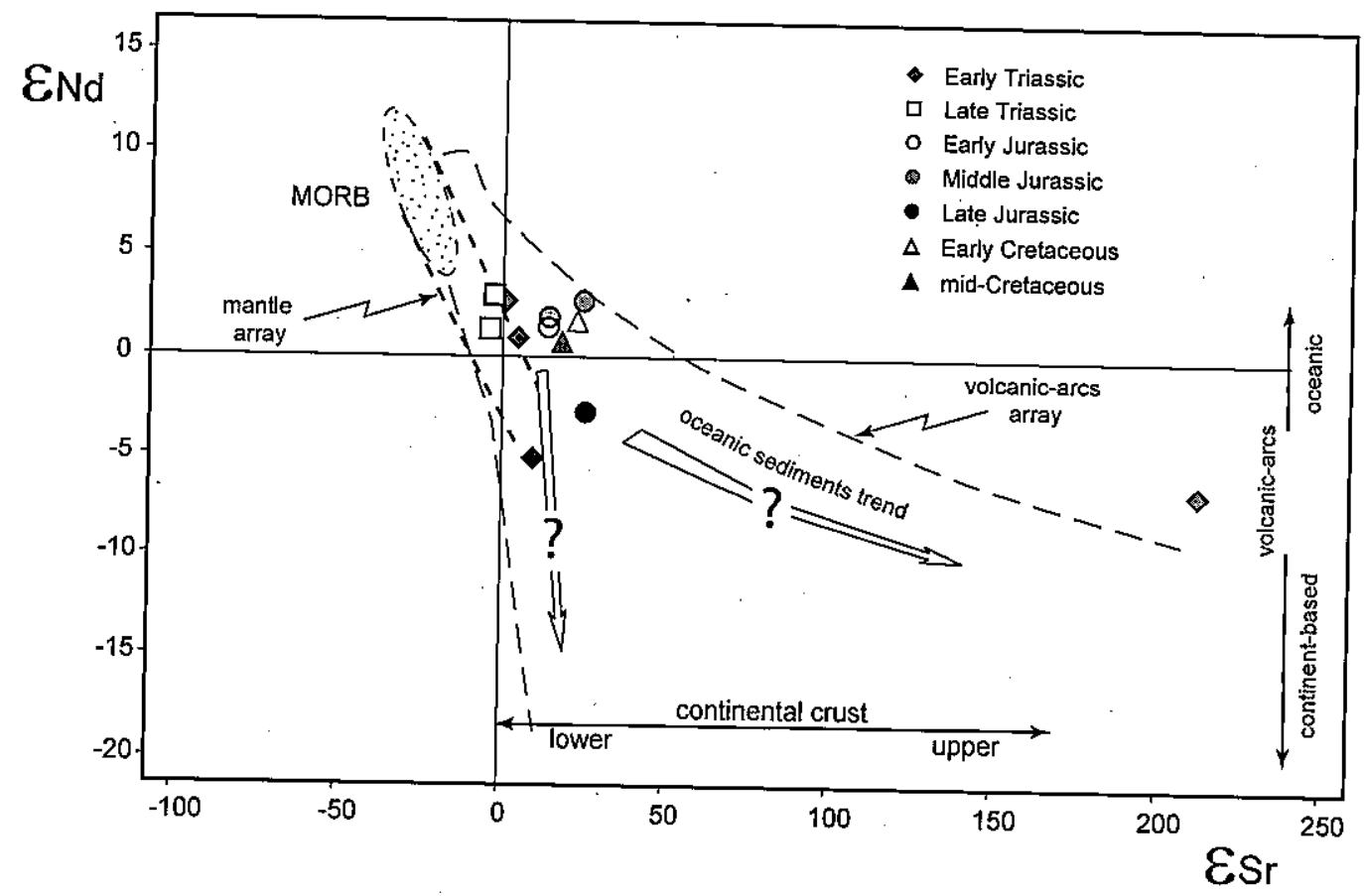




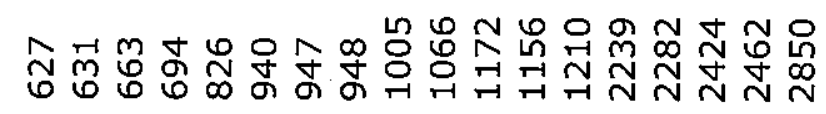

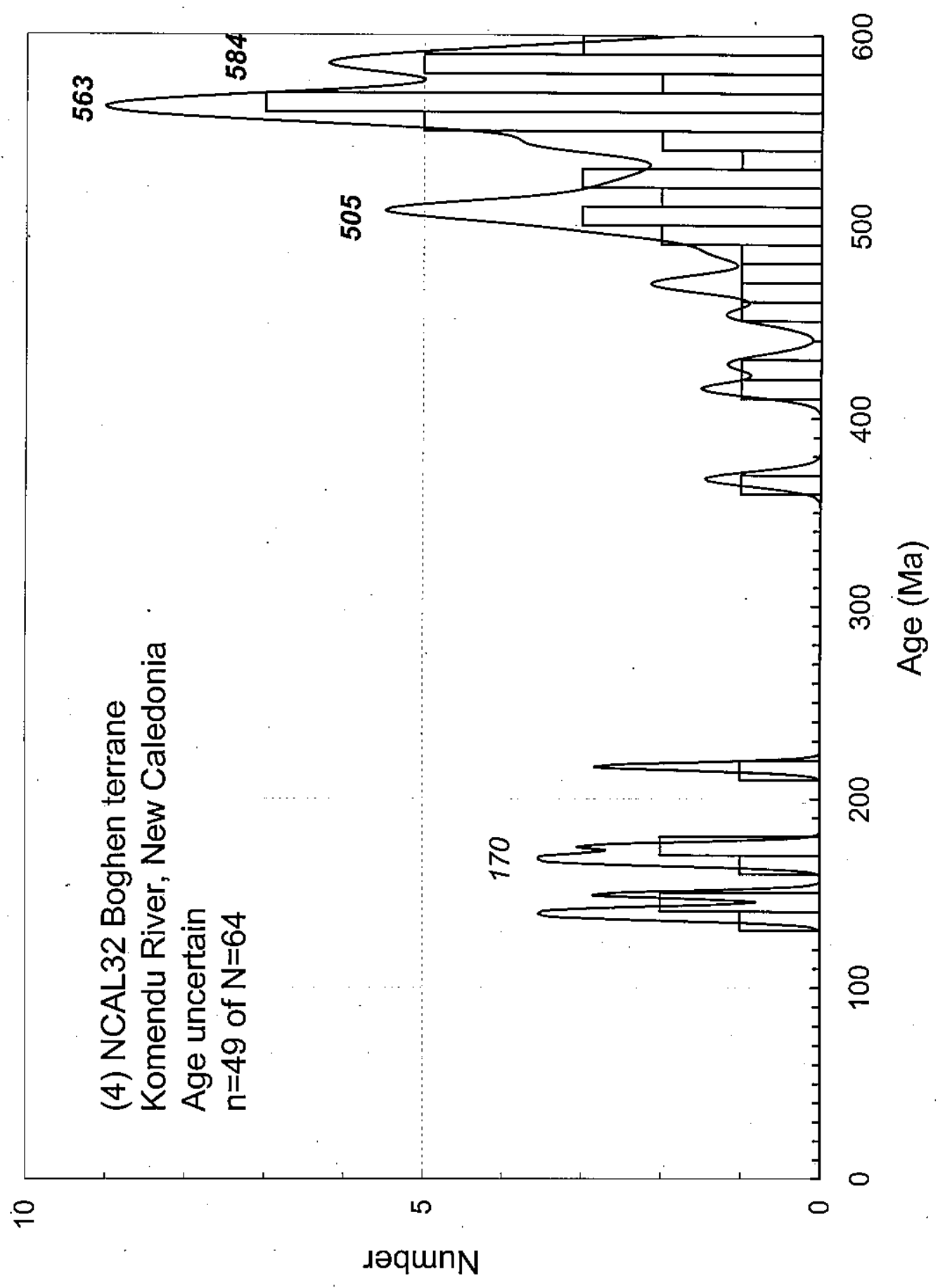



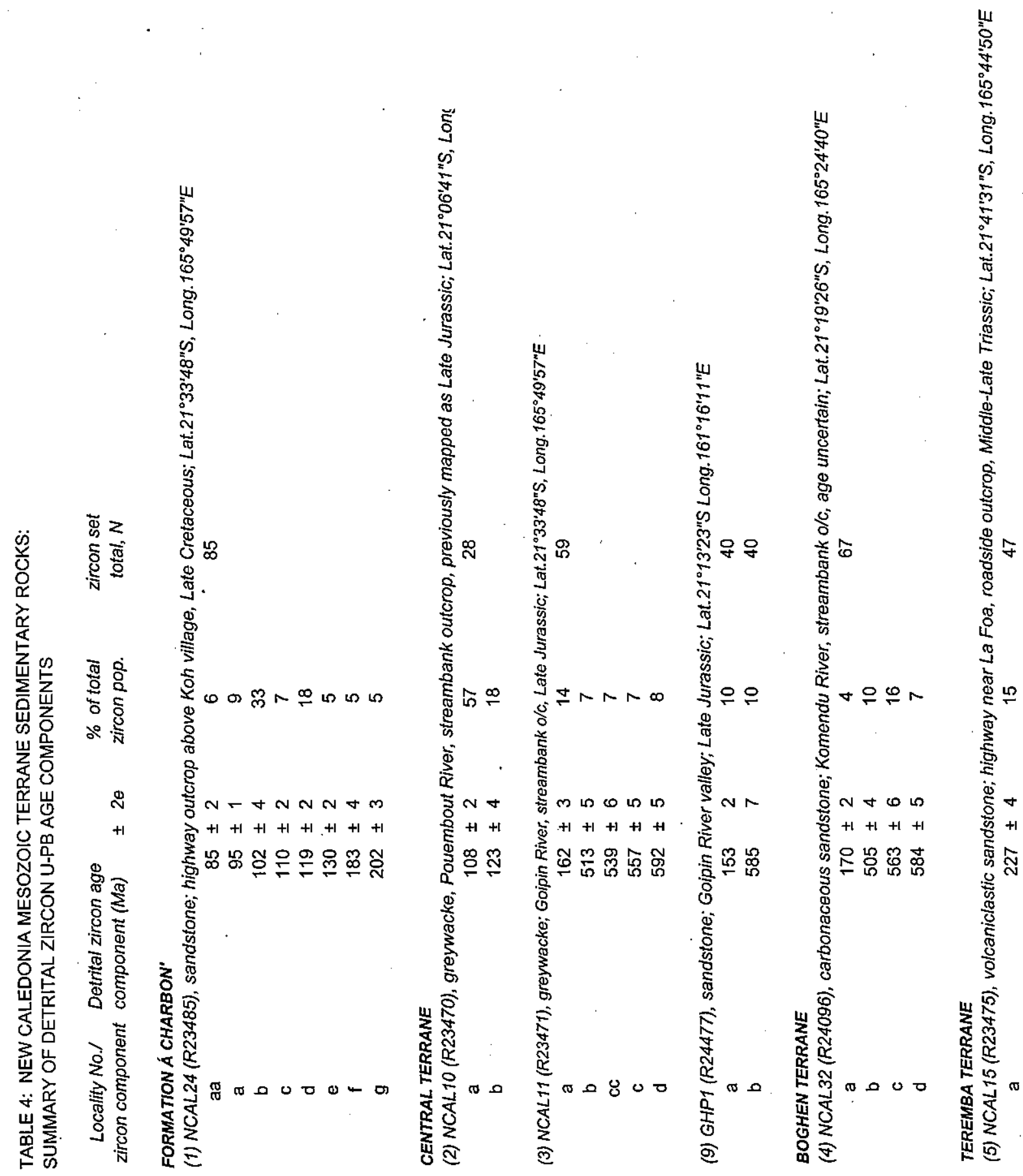


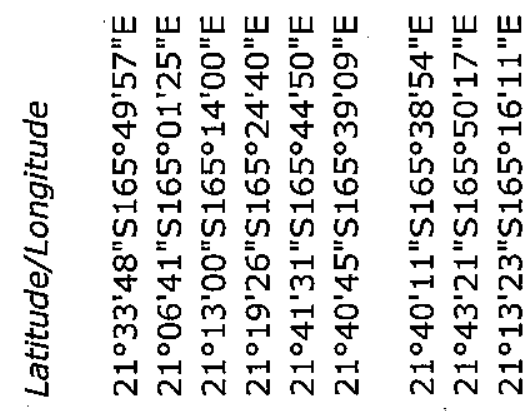

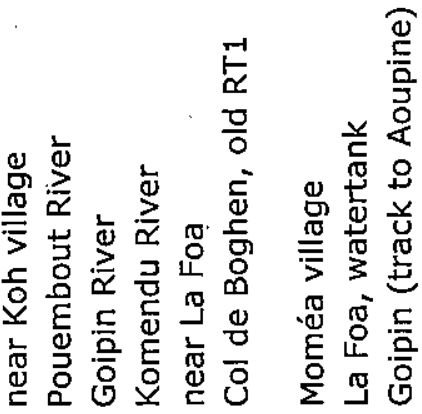
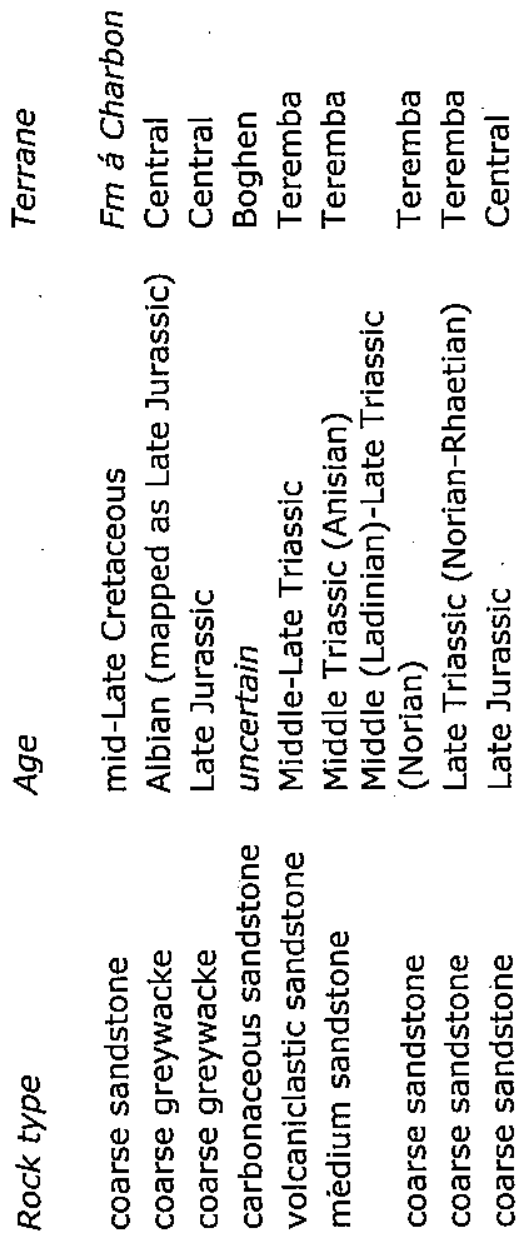

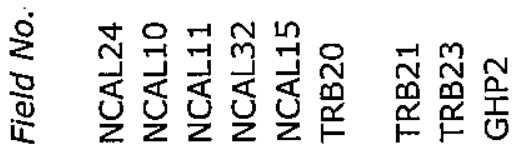

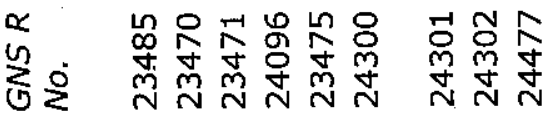

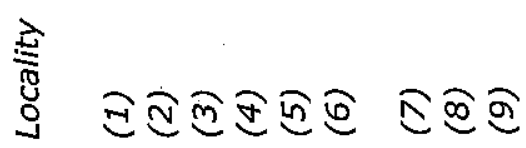




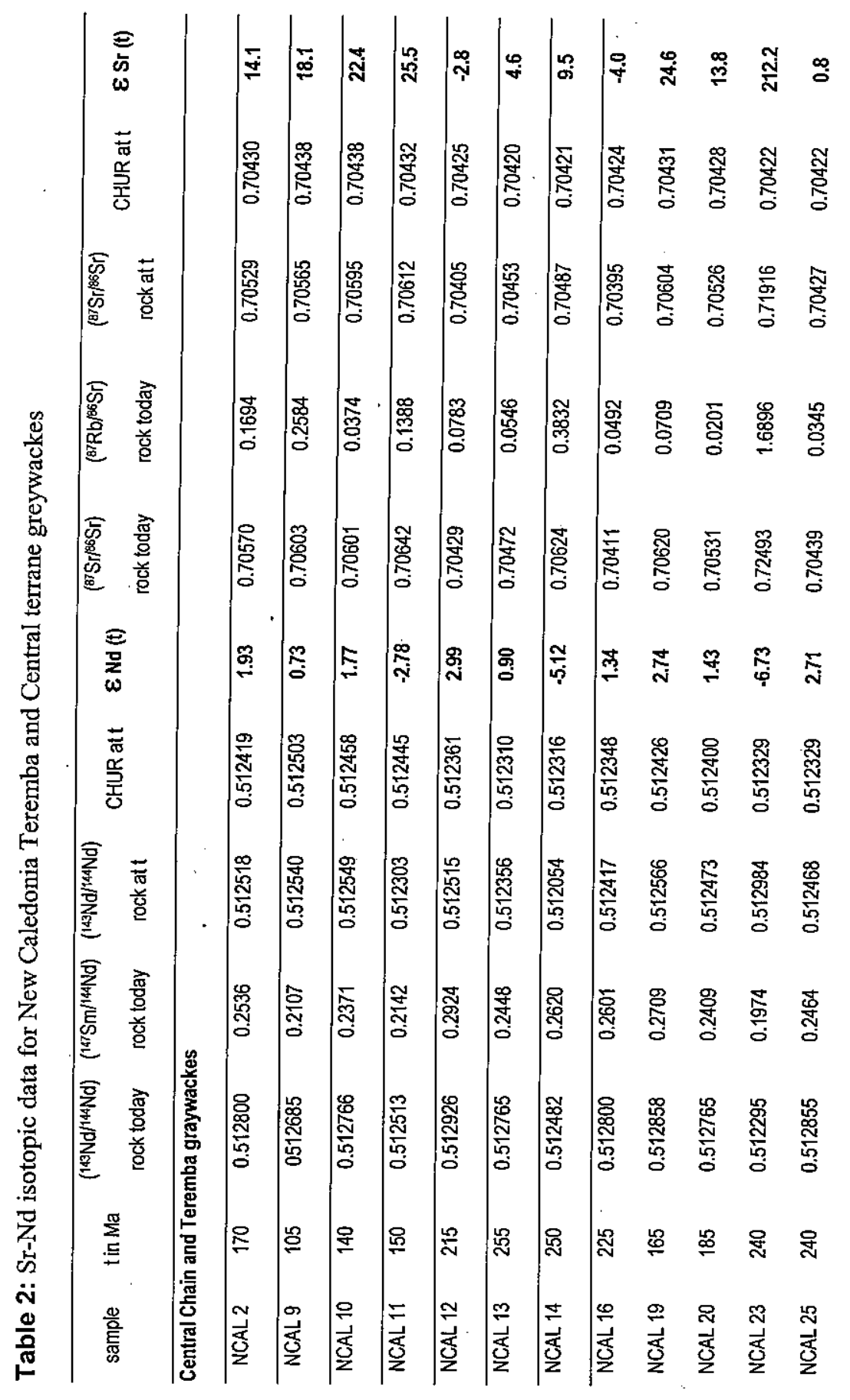




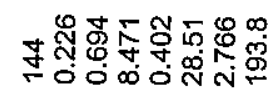

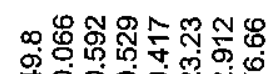

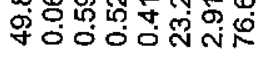

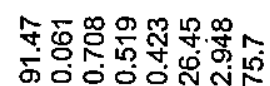

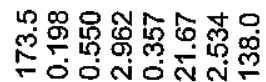

ำํำํํำำำ

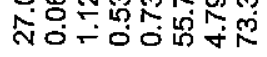

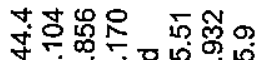

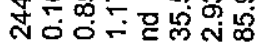

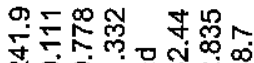

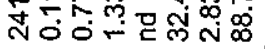

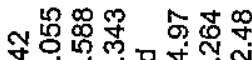

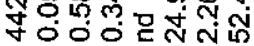

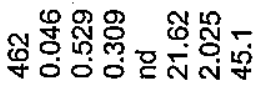

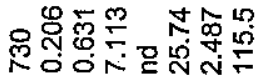

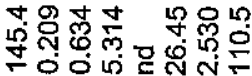

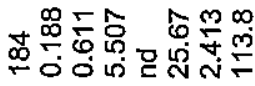

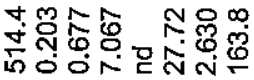

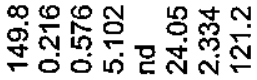

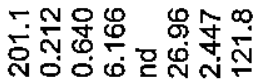

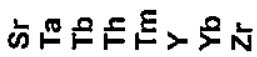




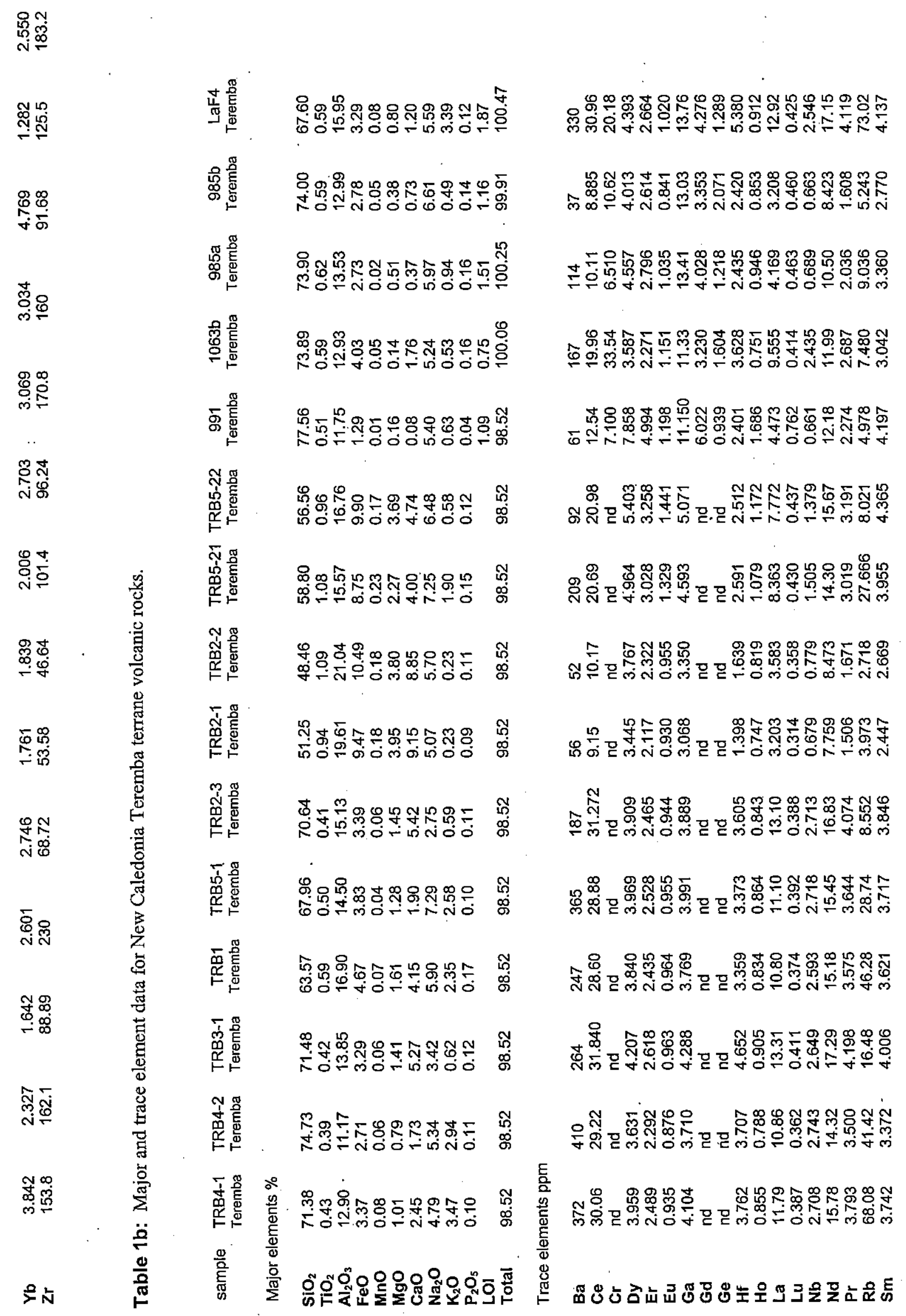




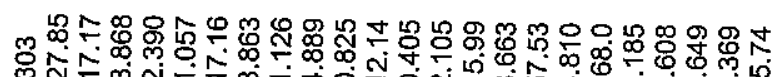

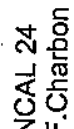

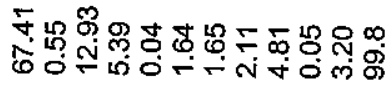

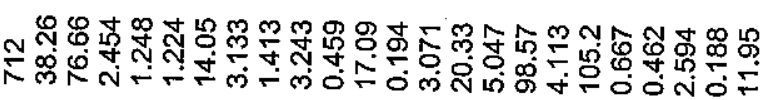

决絮

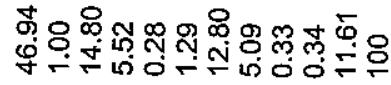

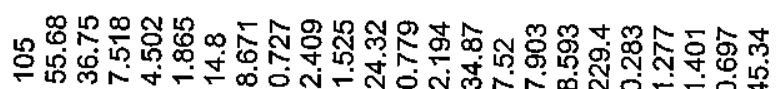

蛋

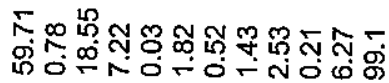

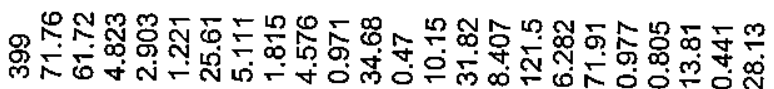

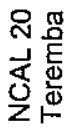

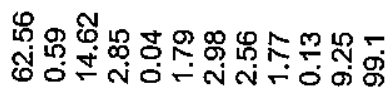

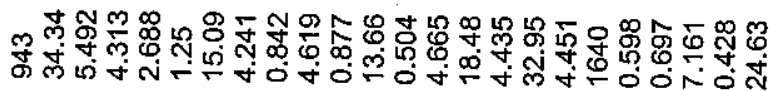

욤

它

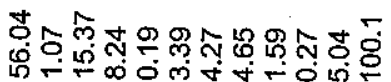

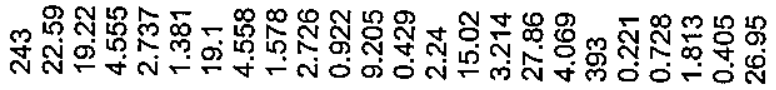

$\stackrel{0}{\frac{\pi}{4}}$

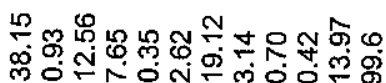

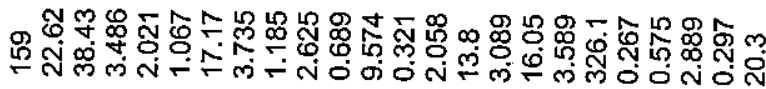

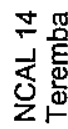

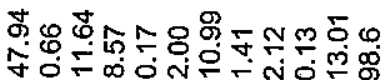

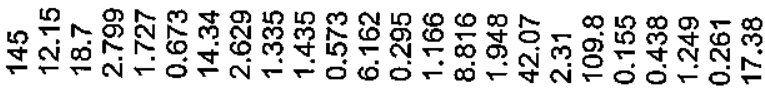

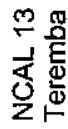

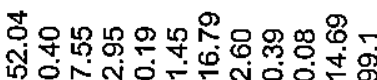

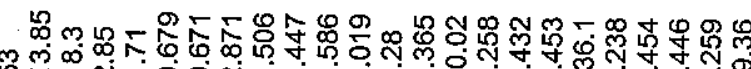

ถึ

№

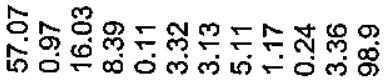

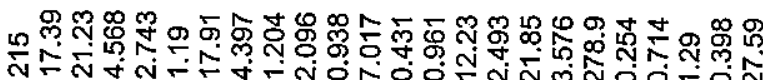

焉

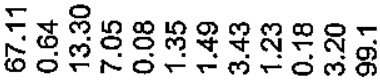

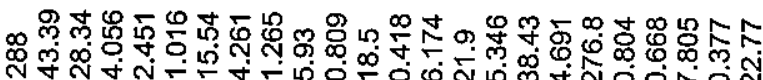

오

逐焉

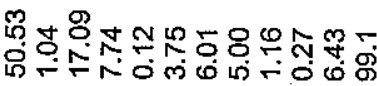

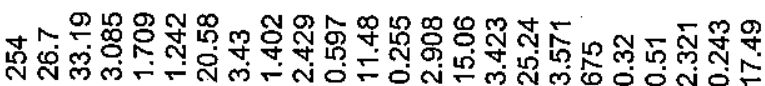

焉焉

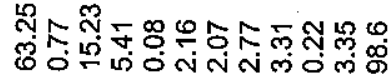

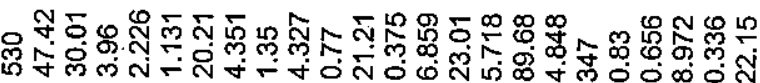

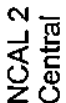

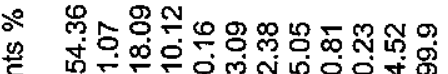

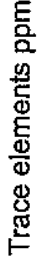

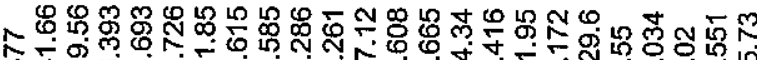

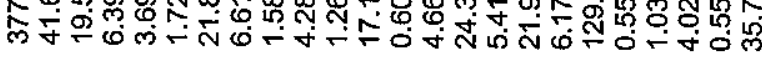

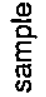

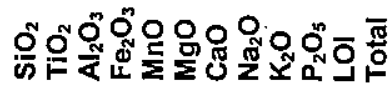

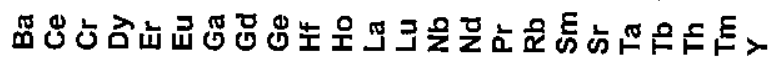



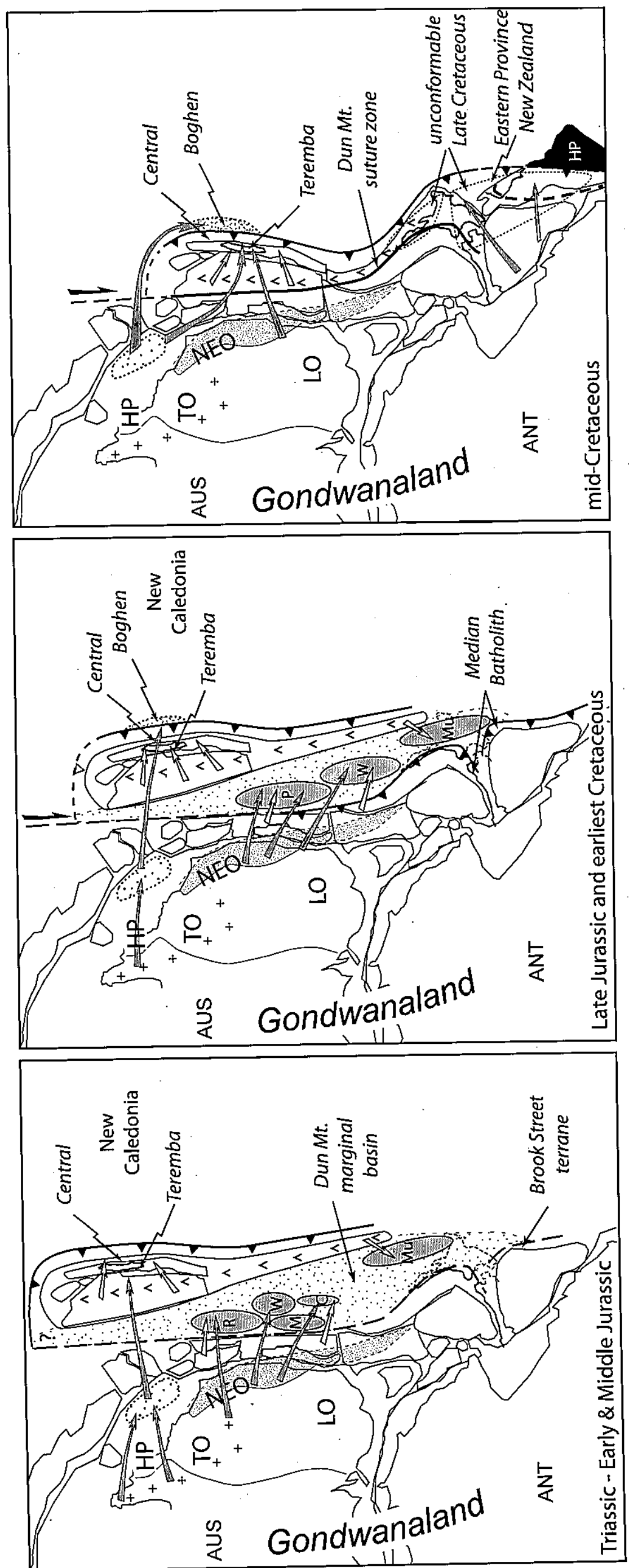


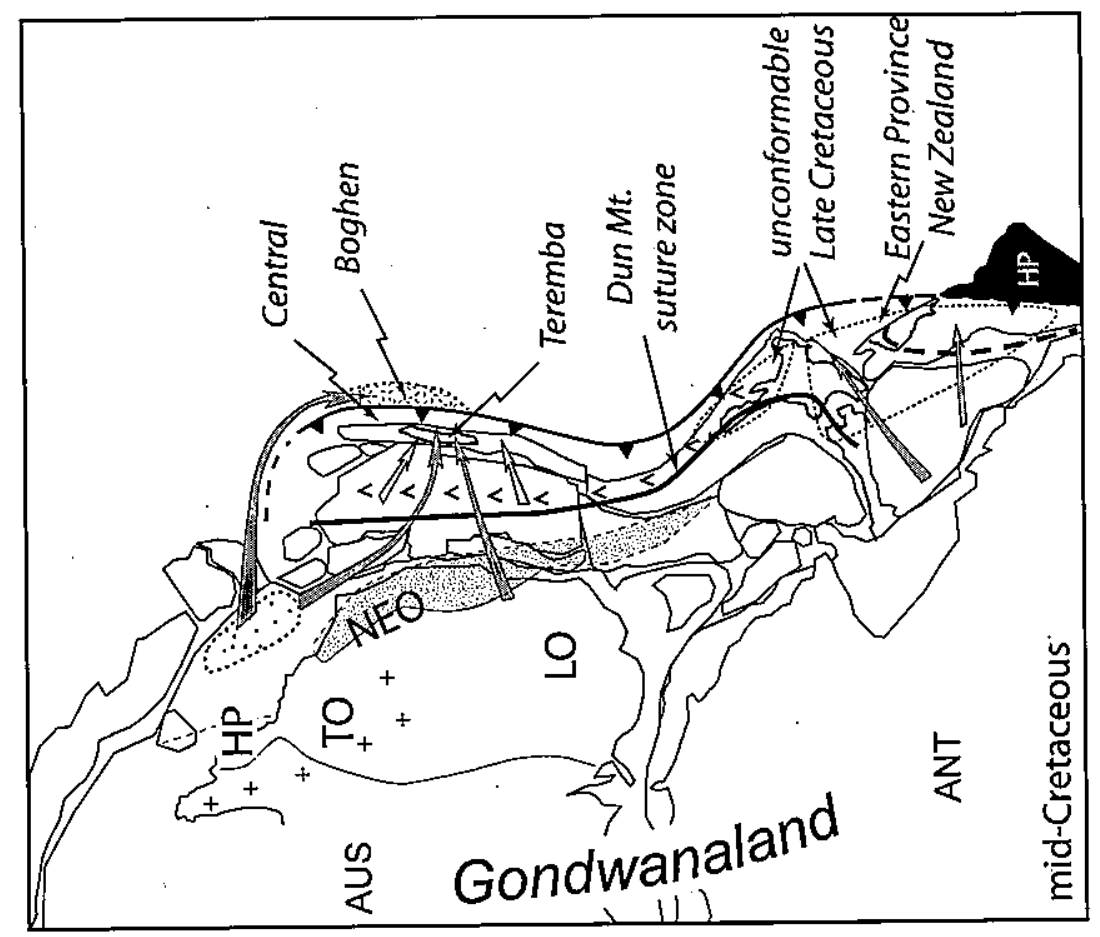

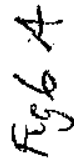
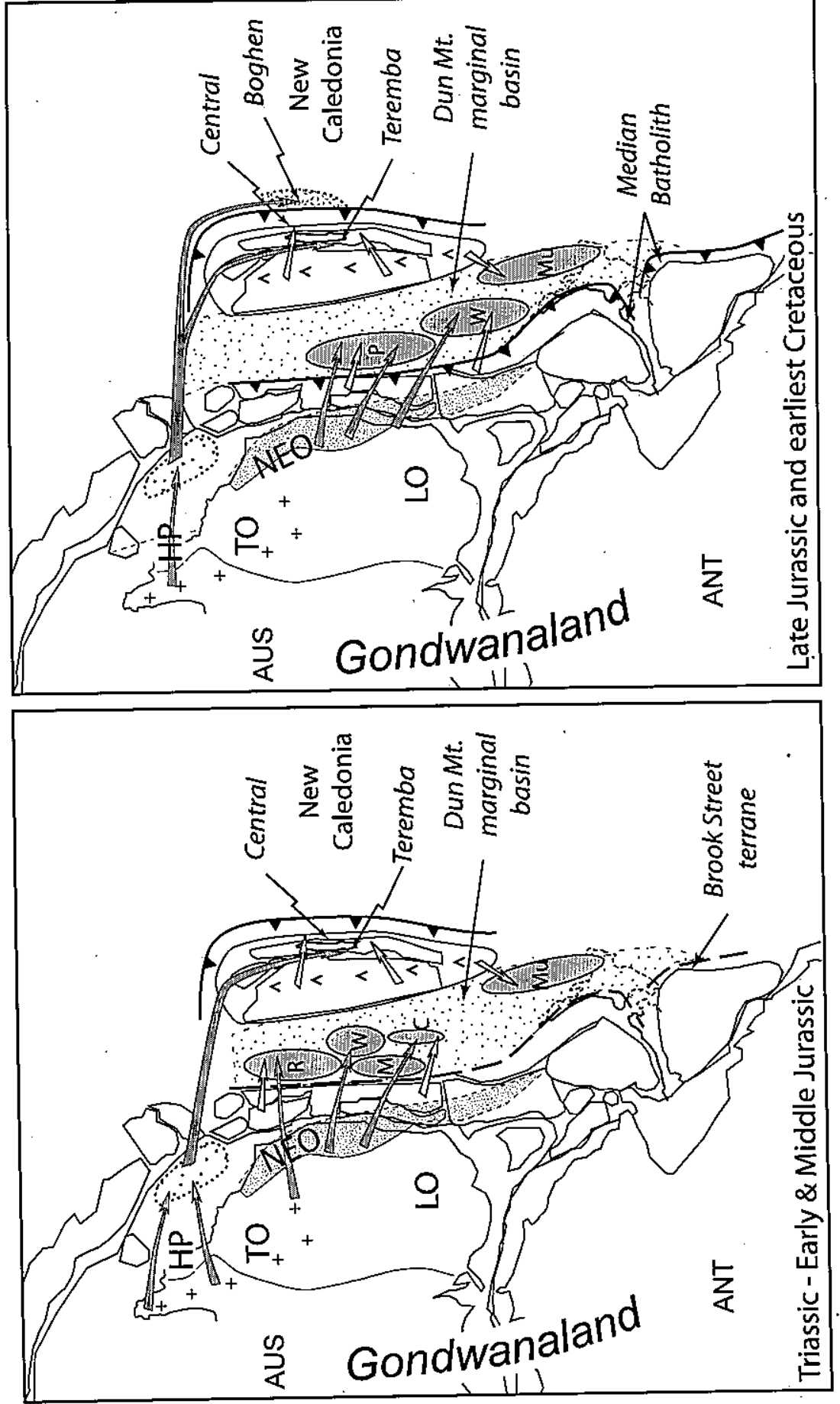


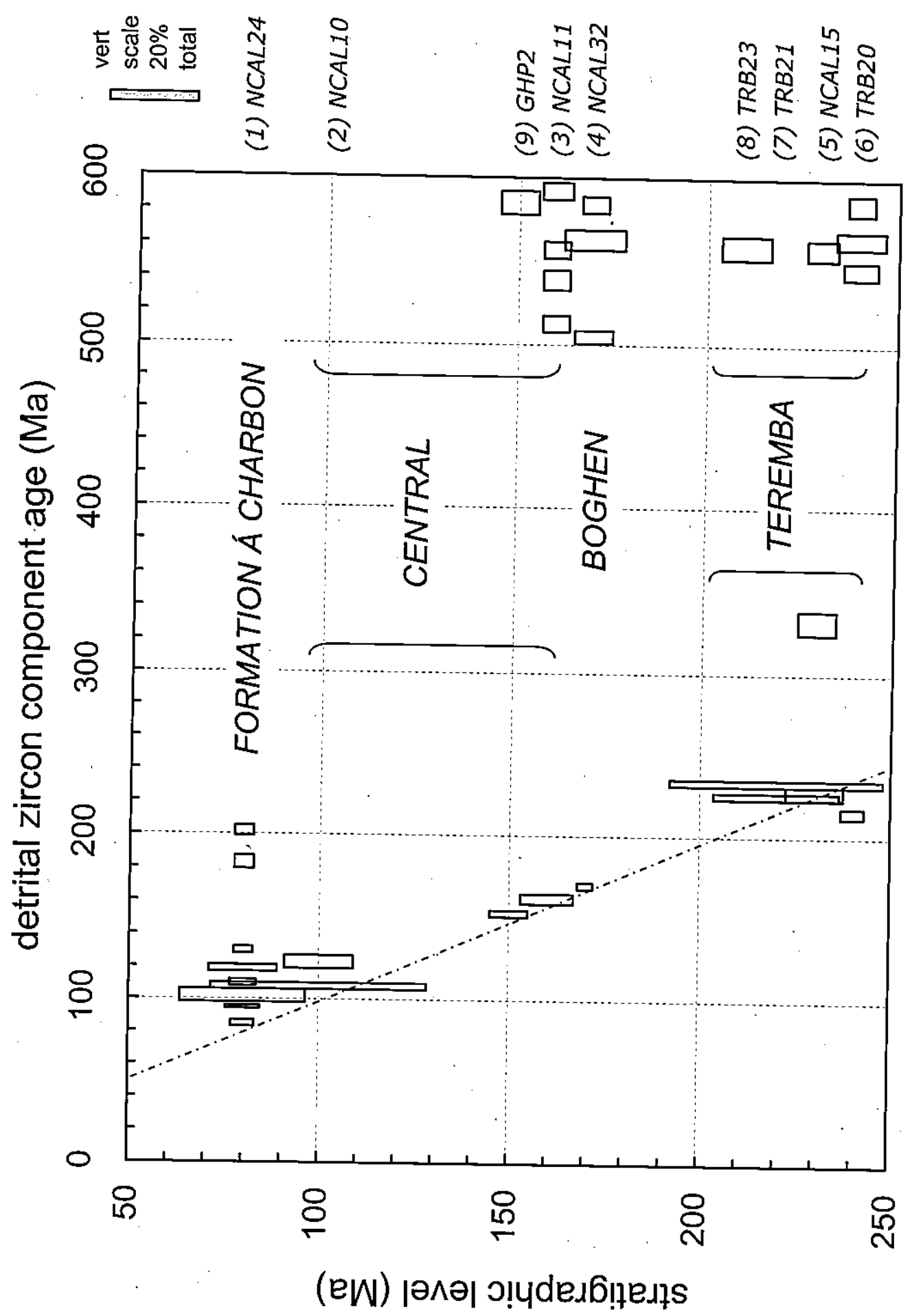




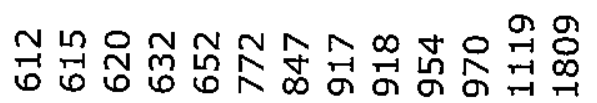

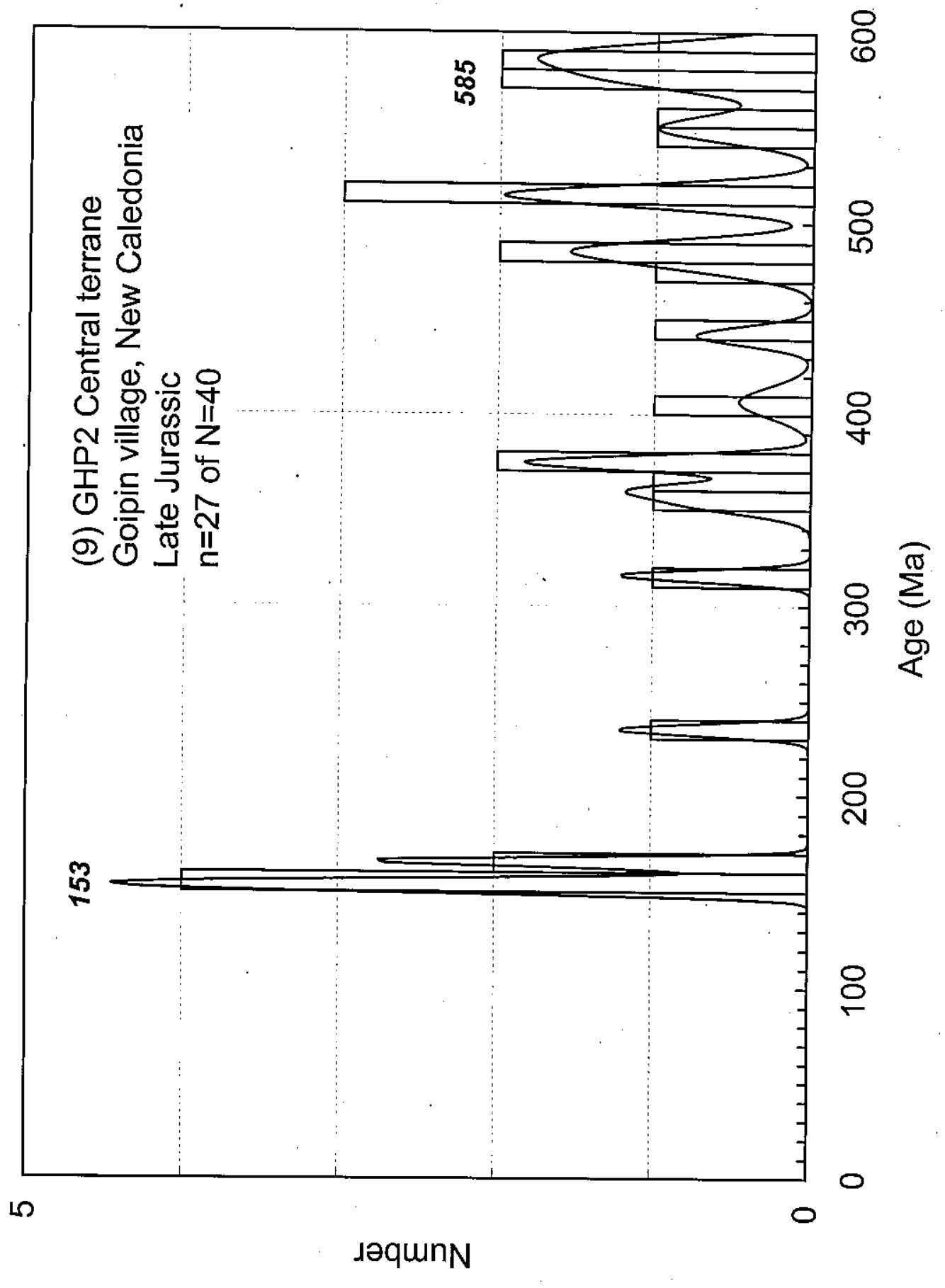




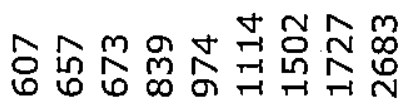

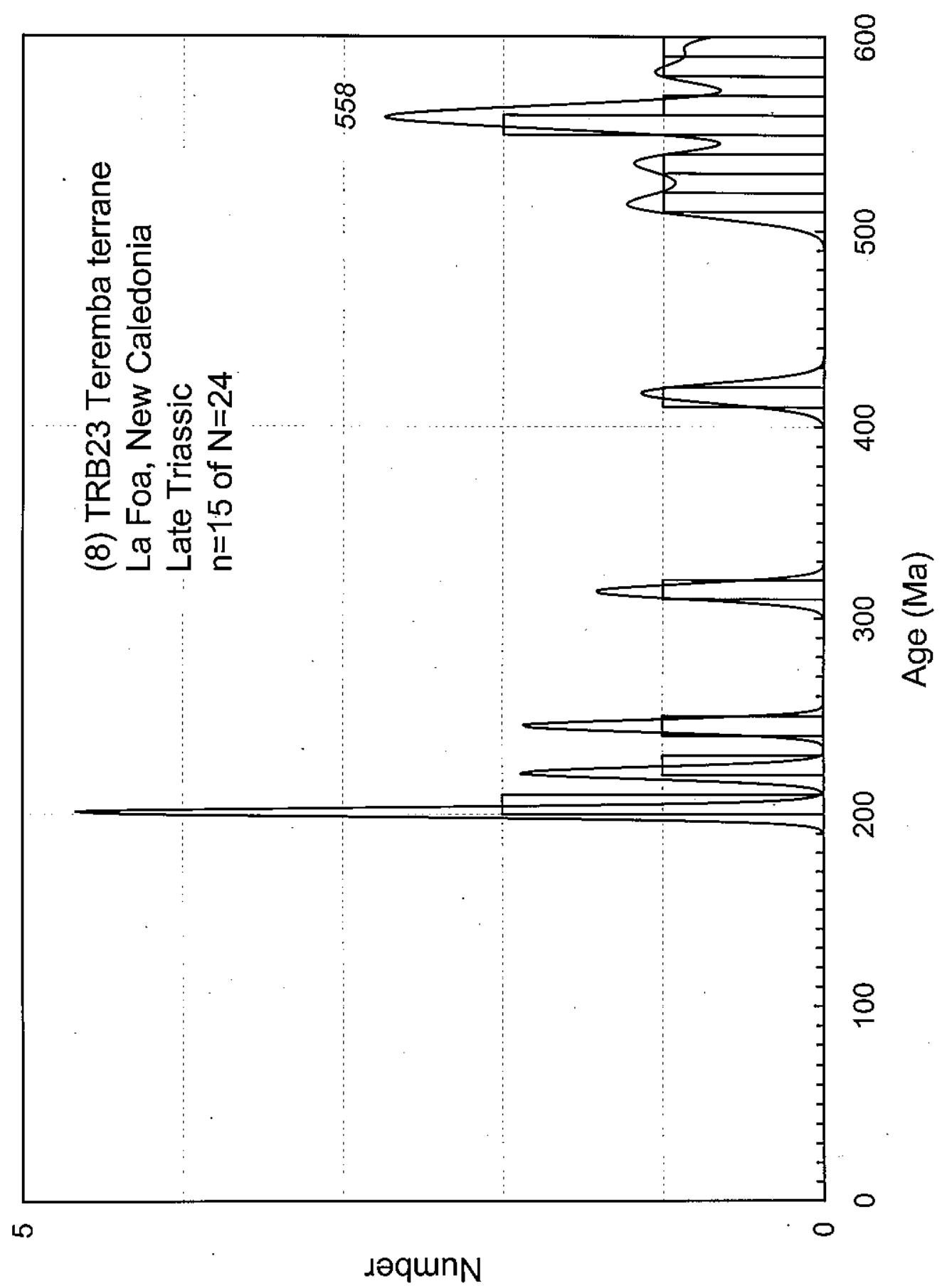




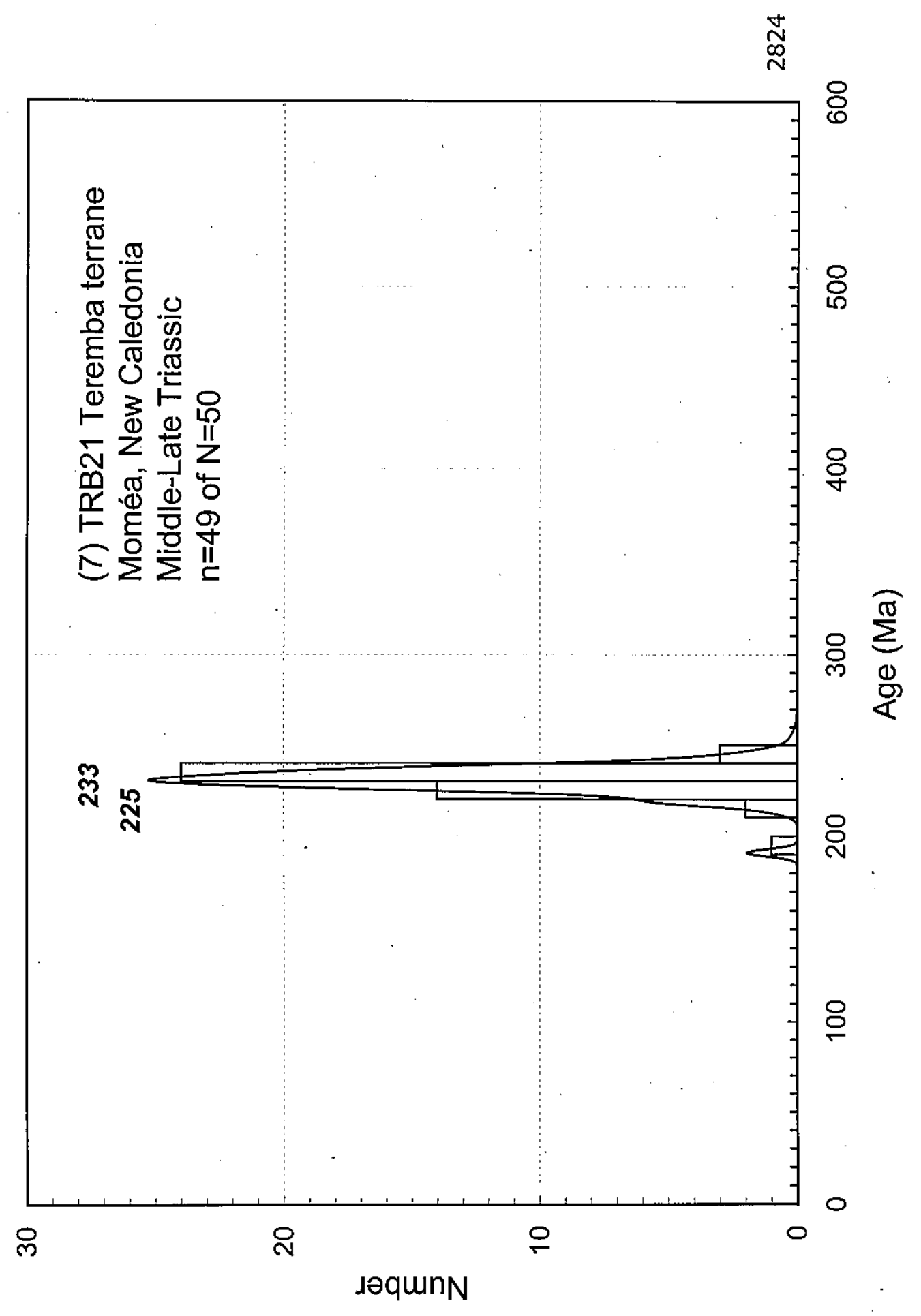




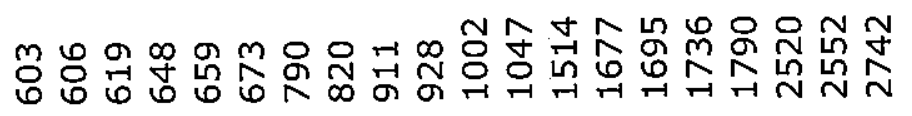

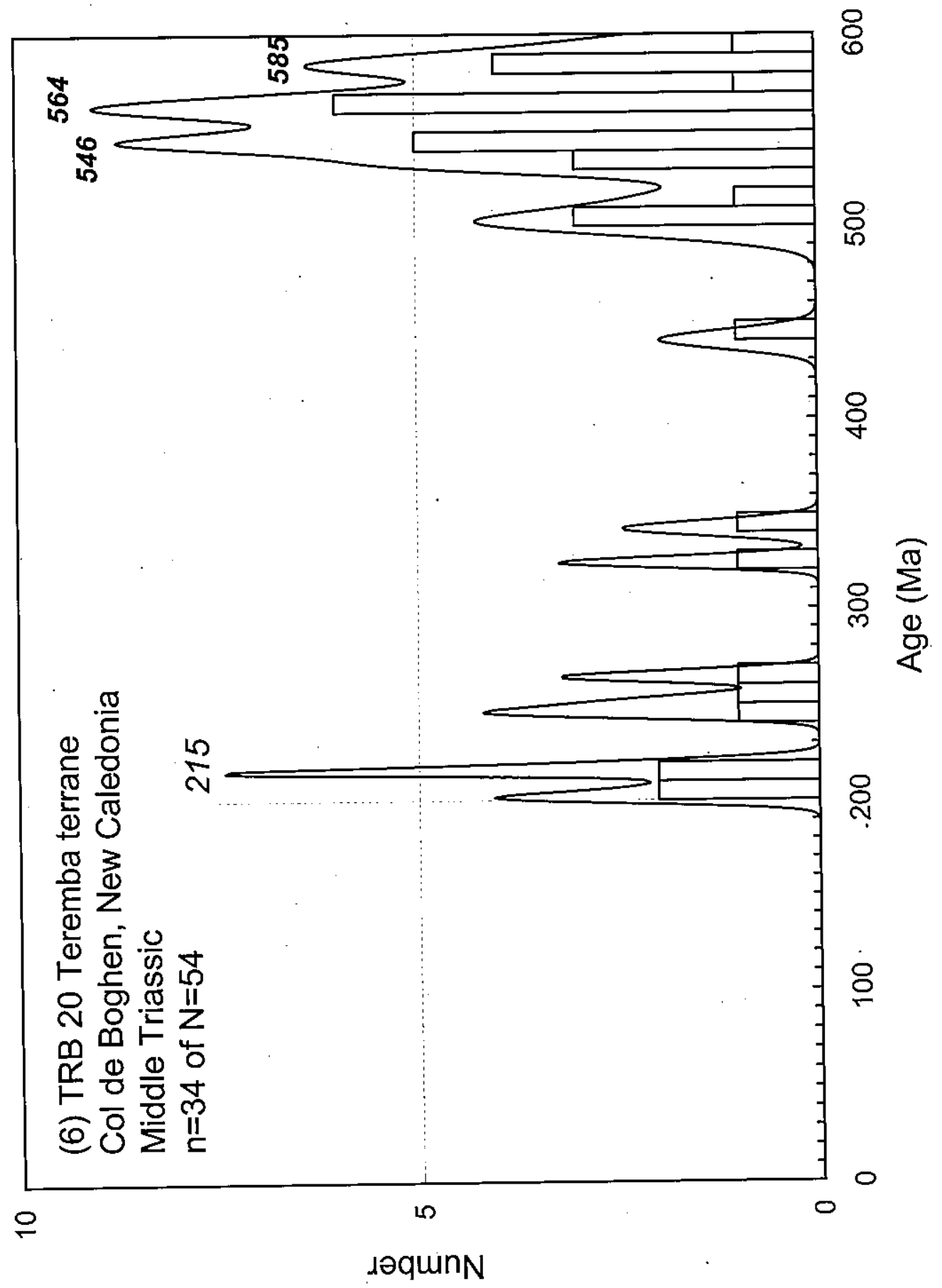




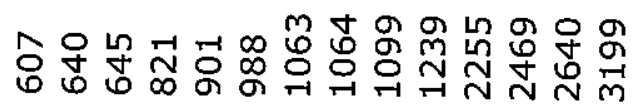

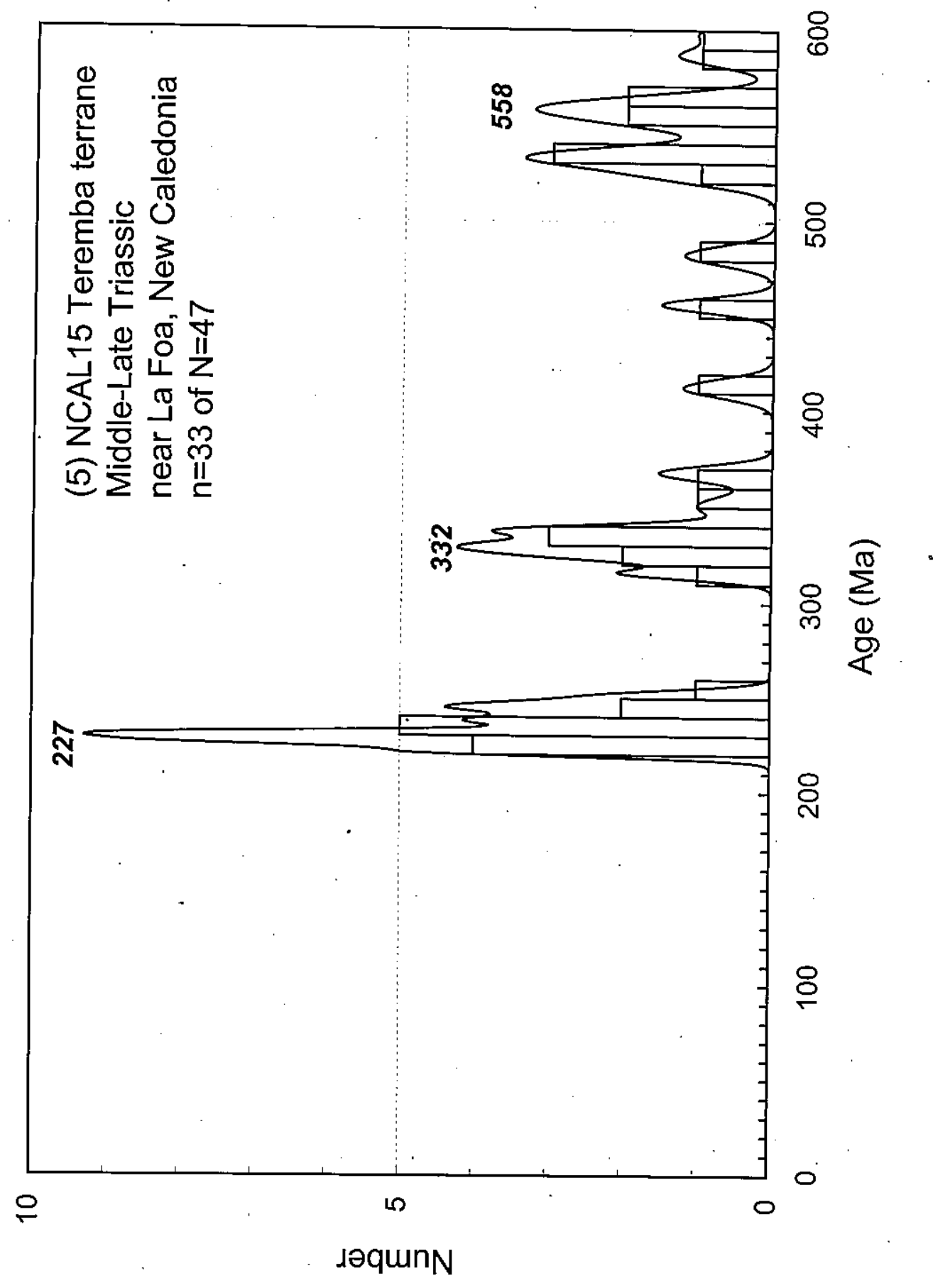




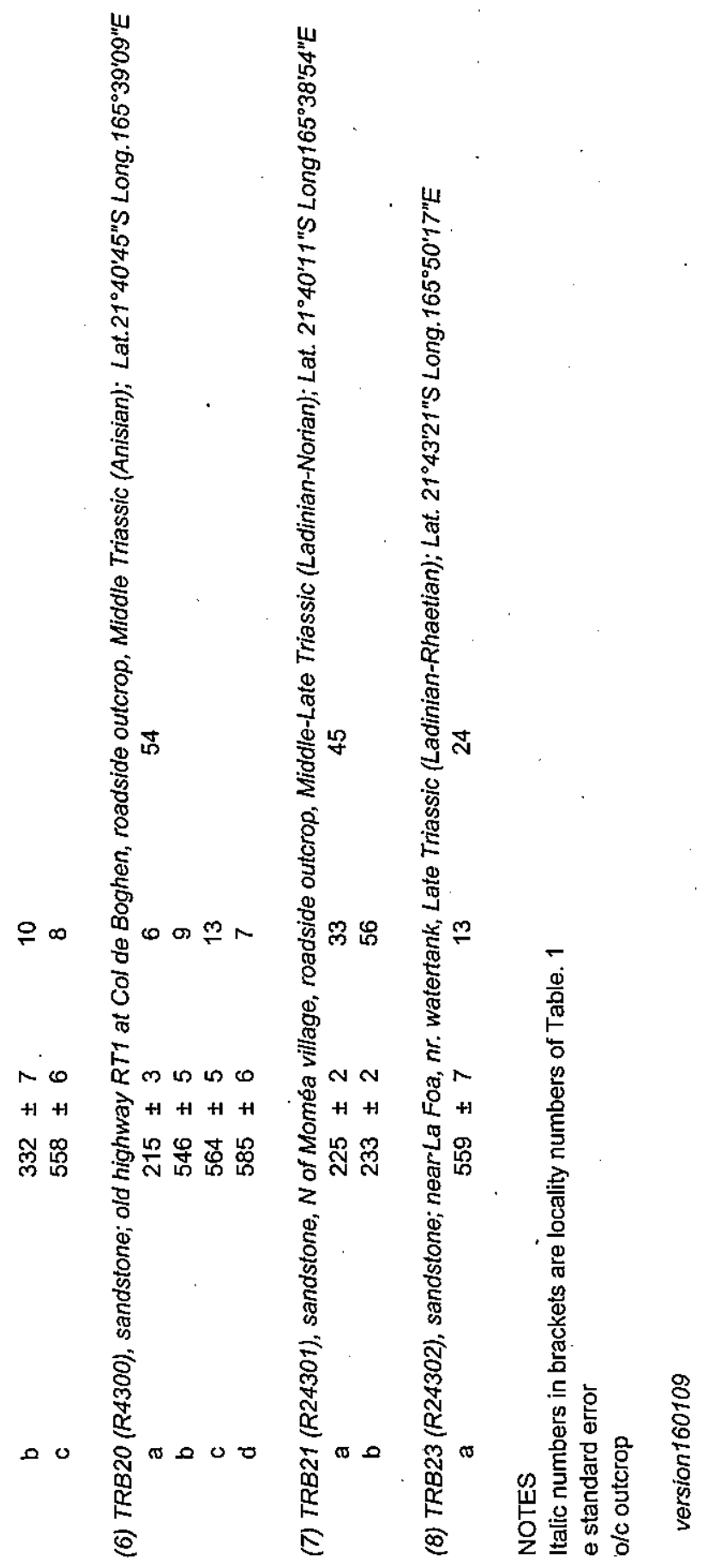




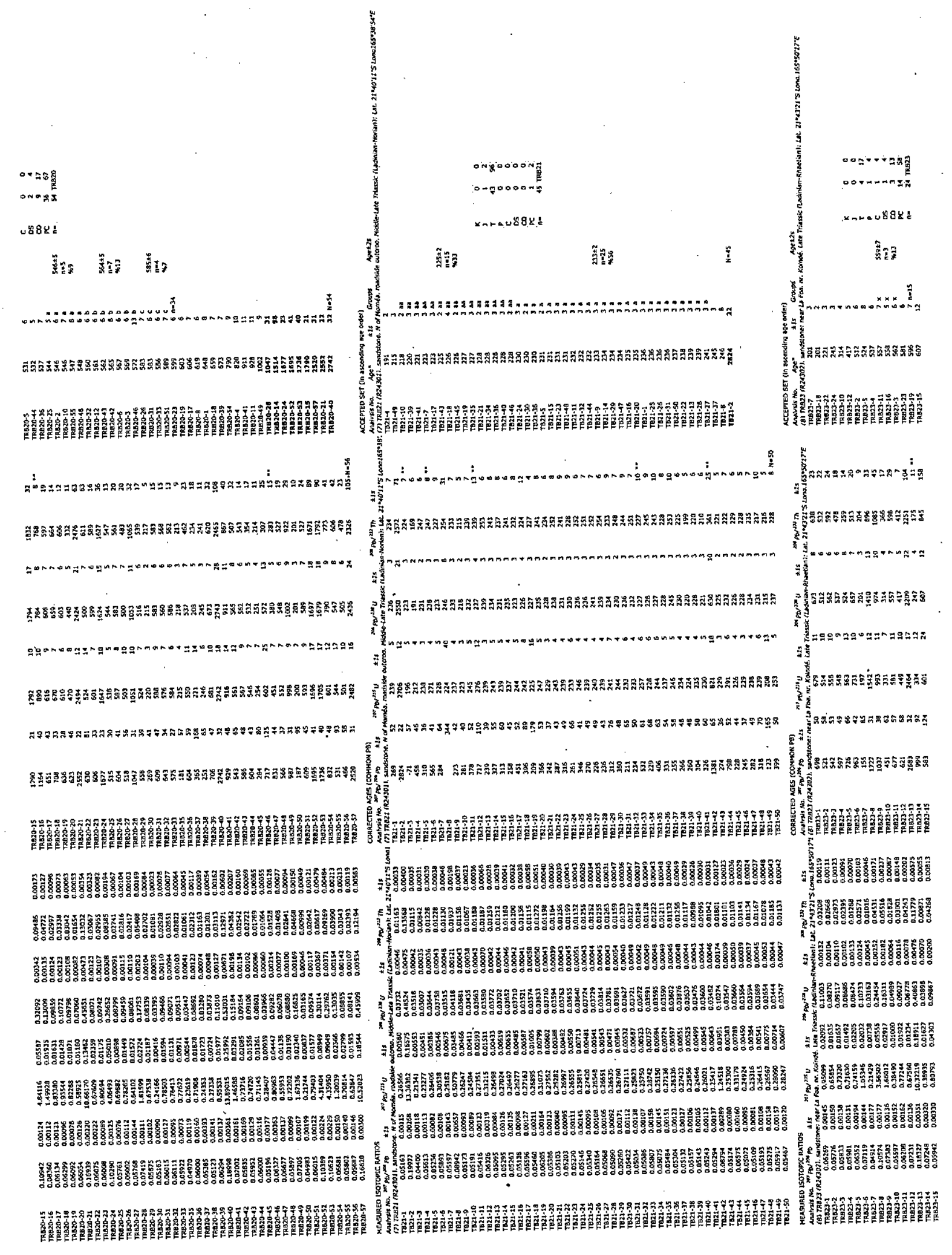




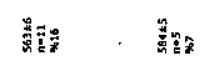

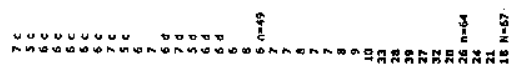

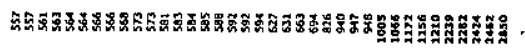

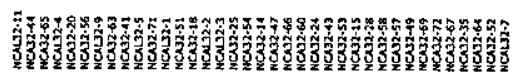

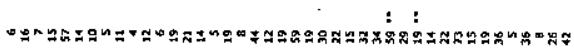

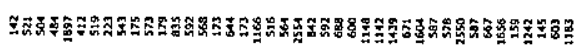

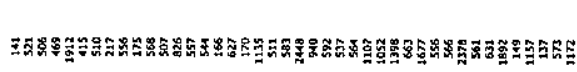

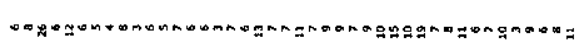

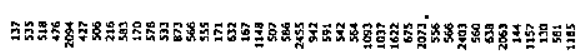

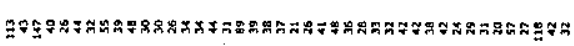

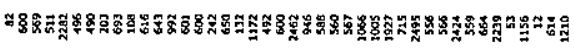

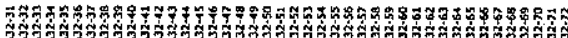

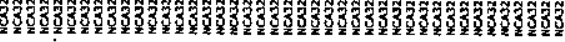

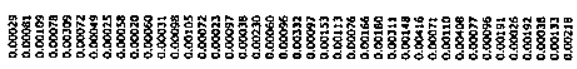

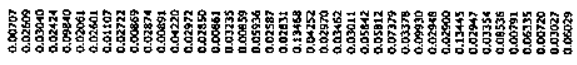

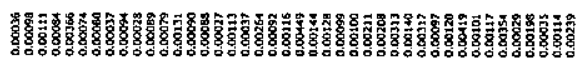

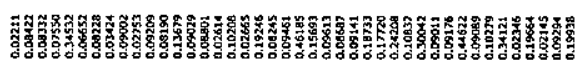

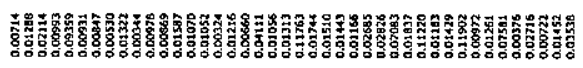

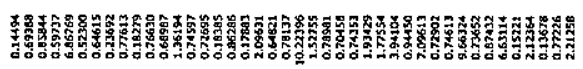

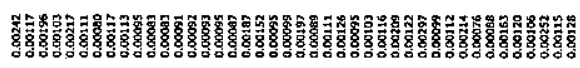

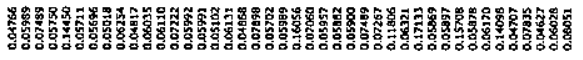
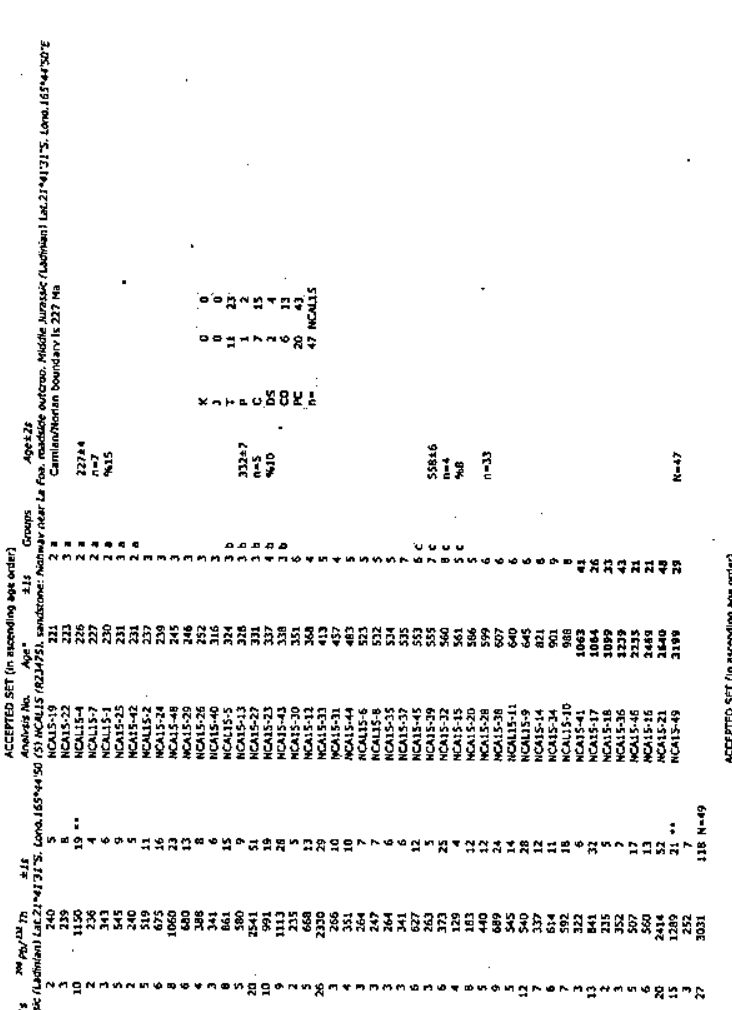
it

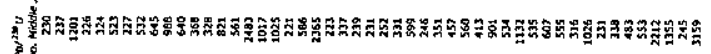
$\sqrt{8}$

"意

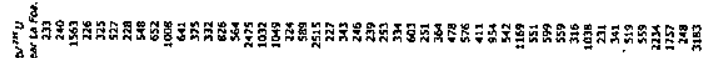
站

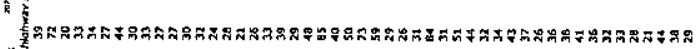

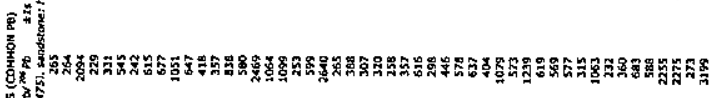
这然

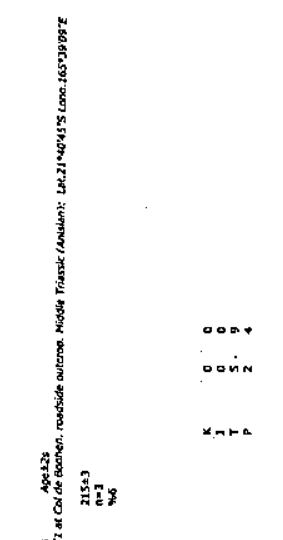

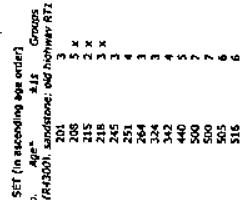

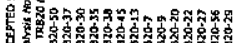

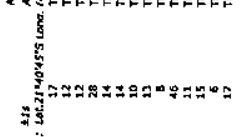

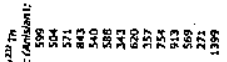
(1)

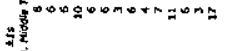

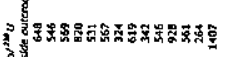
存弯

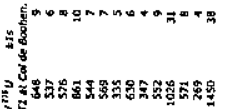
策 คำ $2 \frac{10}{4}$

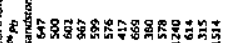
然绻

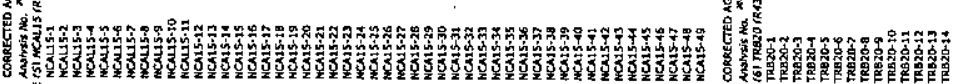
प

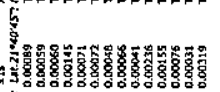
F

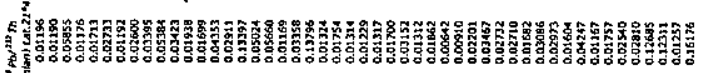

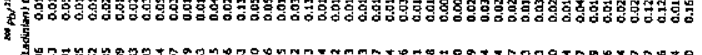

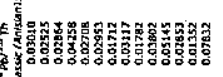
3.

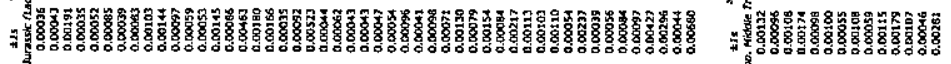

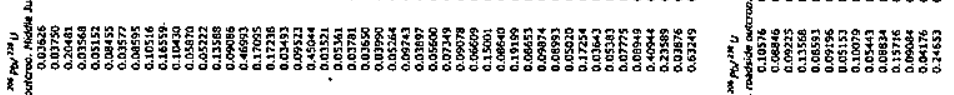

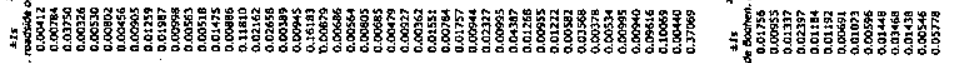

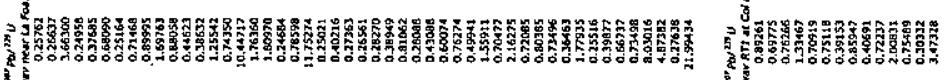

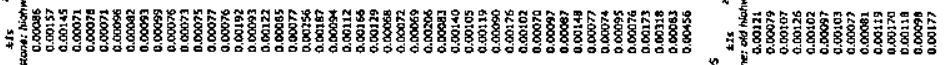

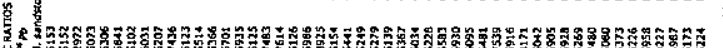

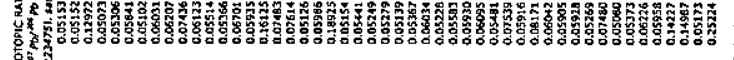

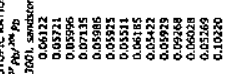

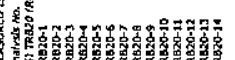




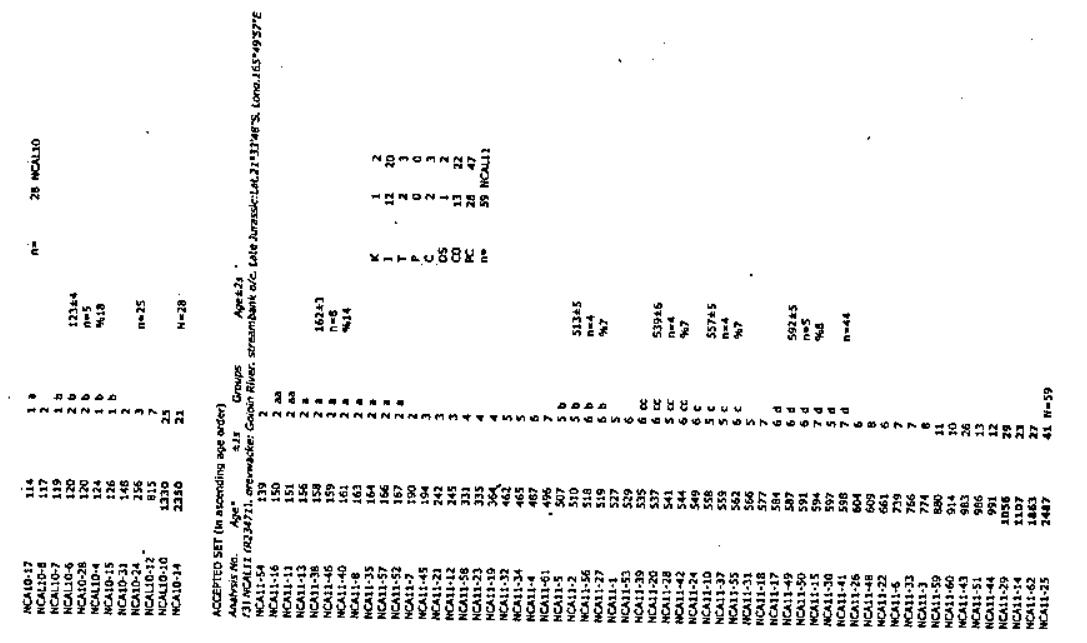

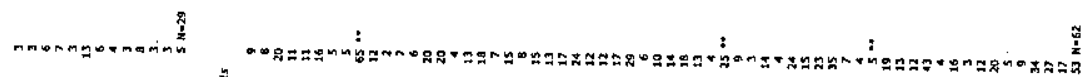

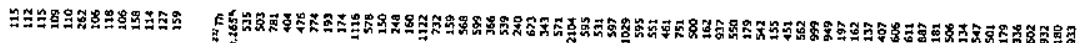

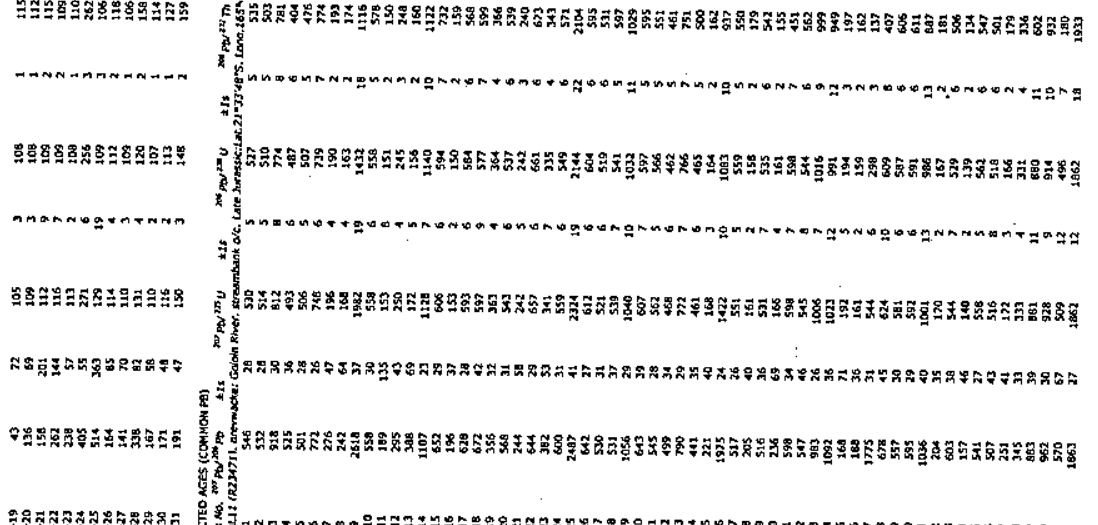

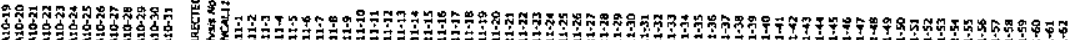

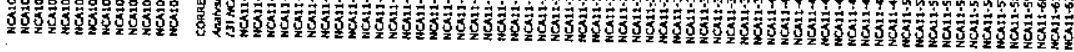

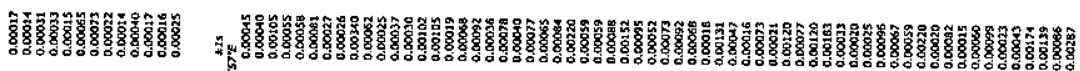

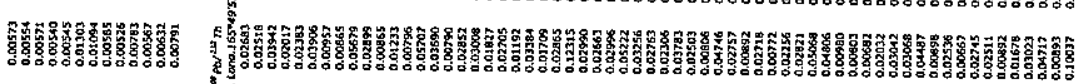

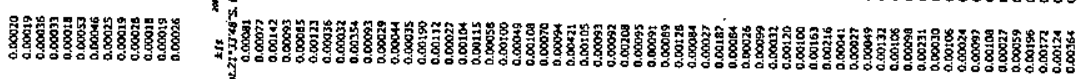

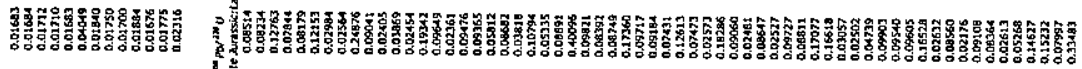

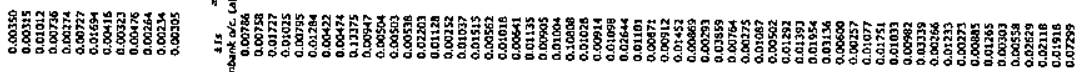

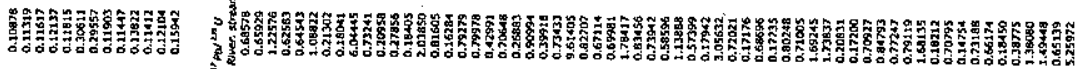

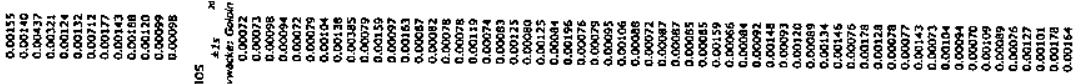

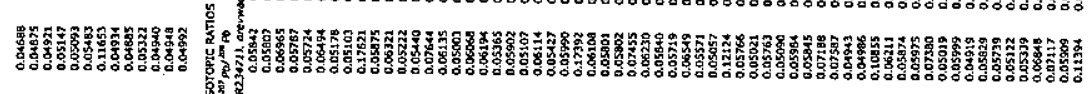

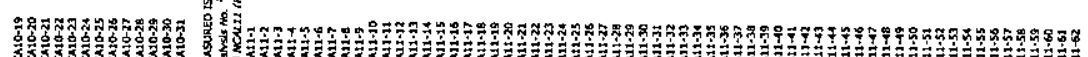

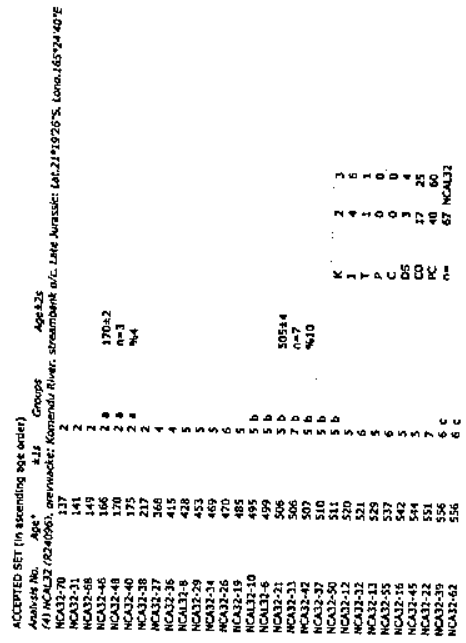
*ี

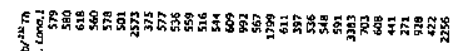

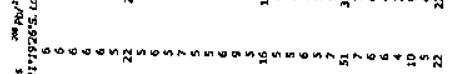

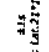

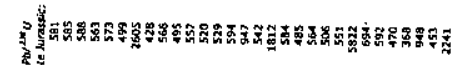
年

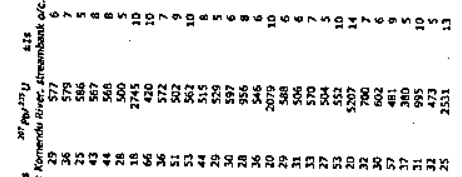

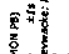

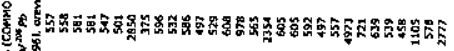
पूर्ष

赵

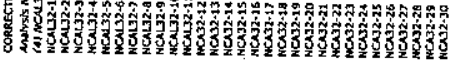

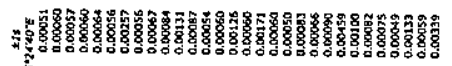
帝

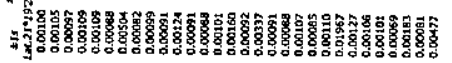

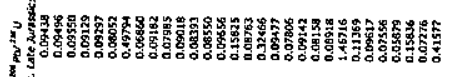

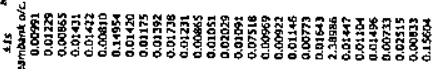

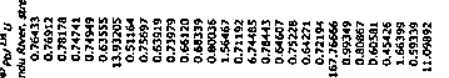

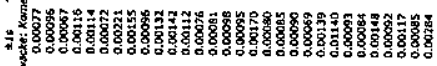

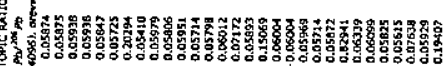

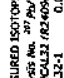

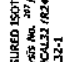

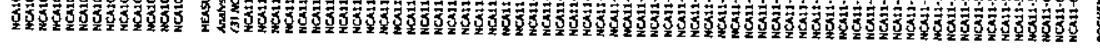



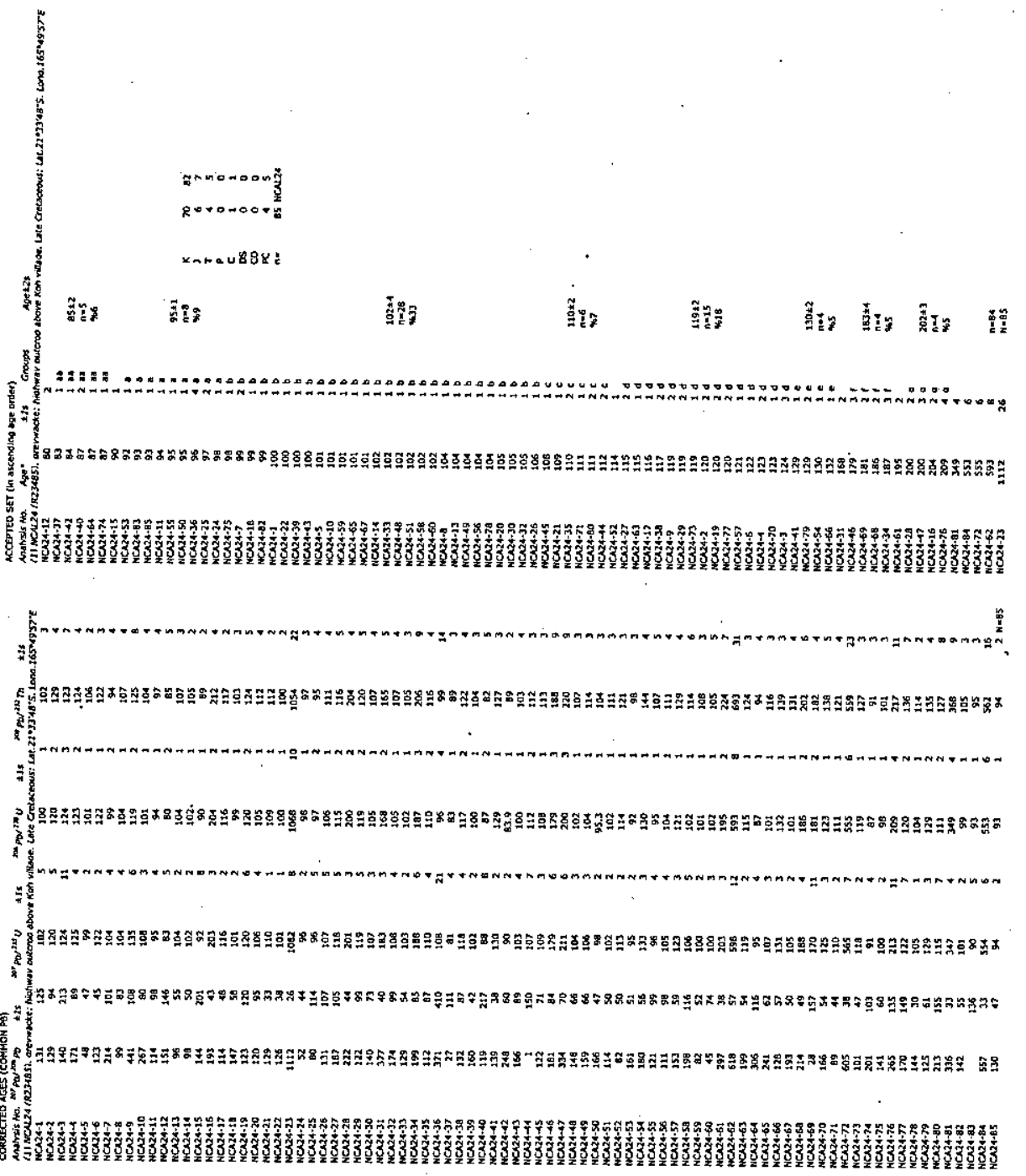

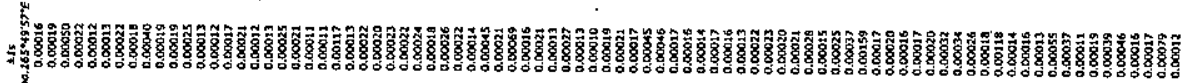
年

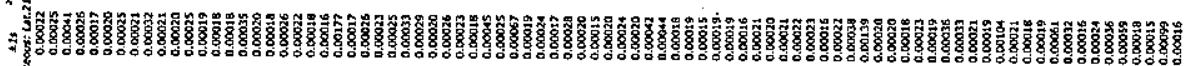

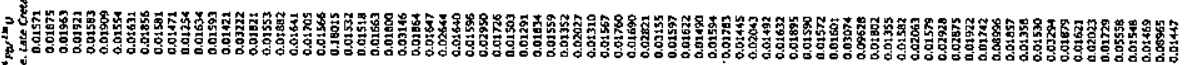
"1

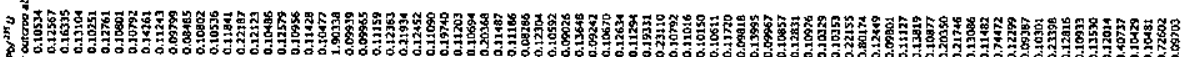
!

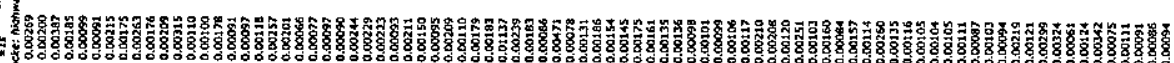

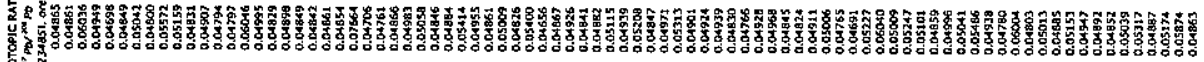

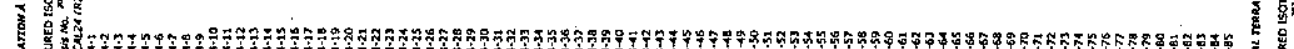
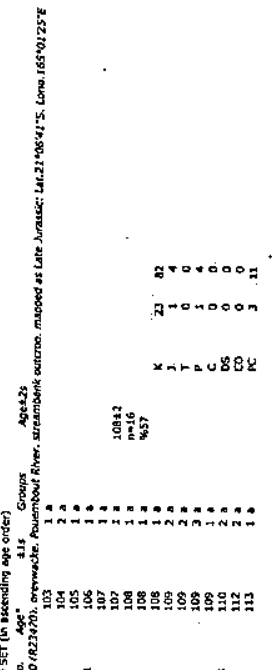

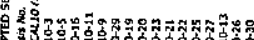
ำㅇำ

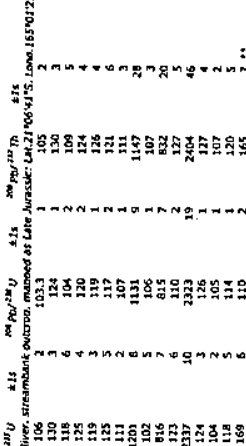

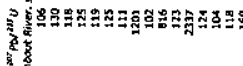
은

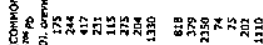

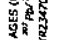

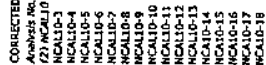

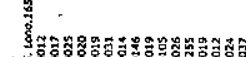

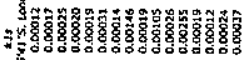

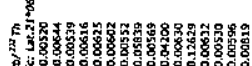
(1) 5ิง

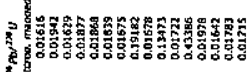

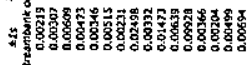

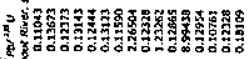

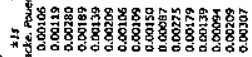
龍 然为

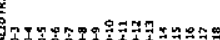

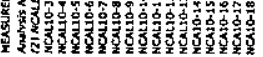


TABLE GA; DETRITAL, ZIRCON AGE DATA FOR NEW CALEOONIA: PERCENTAGE PROPORTIONS IN GEOLOGICAL PERIODS

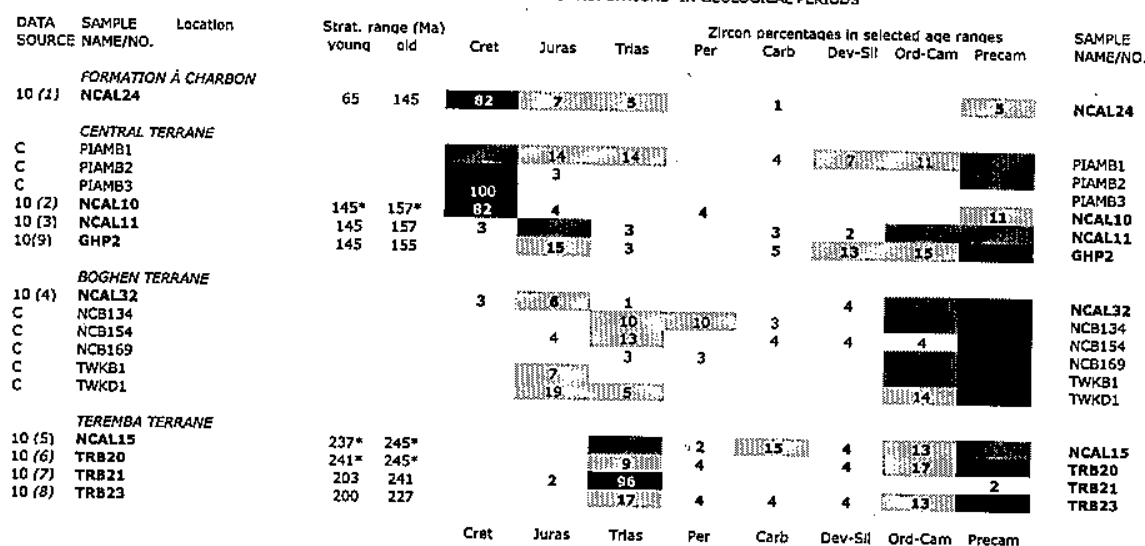

TABLE 68: DETRTAL ZIRCON AGE DATA FOR EASTERN QUEENSLAND TERRANES: PERCENTAGE PROPORTONS IN GEOLOGICAL PERTODS SHOALWATER - BEENLIGH COMPOSITE TERRANE
Shoalwater Terane

Shoalwater Terrane
SHW48 Arthur Polnt

SHW13 Hummock S

$\begin{array}{ll}\text { 982 } & \text { Brfield } \\ 021 / 5 & \text { Byfield }\end{array}$

Beenieigh Terrane
983
Mlaml Bejach

$\begin{array}{ll}\text { 983 } & \text { Mlaml Beach } \\ \text { Gri10 } & \text { Broken Hd } \\ 982 & \text { Broken Hd }\end{array}$

Grmple Terrane

$\begin{array}{llll}\text { GrM36 } & \text { Keafton } & 200 & 241 \\ \text { GrM106 } & \text { Eldorado Mine } & 251 & 260\end{array}$

Neranweod Fernvale Belt
$984 \quad$ Neranwood

SOUTH D'AGURLAR BLOCK

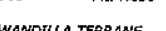

WANDILA TERRANE

$\begin{array}{ll}\text { WAN3D } & \text { Alliator Ck } \\ \text { GBS } & \text { Gladstone } \\ \text { WAN1 } & \text { Gladstone }\end{array}$
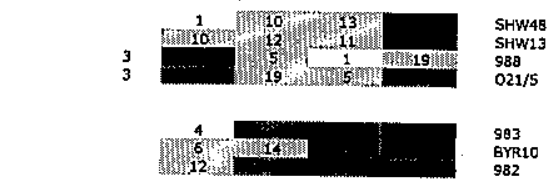

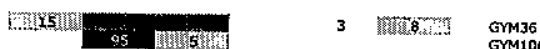

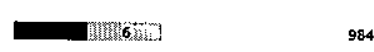

[20 3 2.

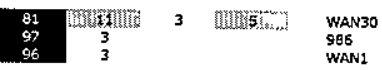

Cret Juras Trlas Per Carb Dev-Sil Ord-Cam Precam

DATA SOURCES

10 this wook, detas hightightod in bid lype

A Adems, unpublethod dets

keallt numbers in brackets referer to localitly numbers of this study (Table 1$)$

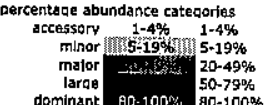


TABLE SA: DETRTAL. ZIRCON AGE DATA FOR NEW CALEDONIA: PERCENTAGE PROPORTIONS IN GEOLOGTCAL PERIOOS

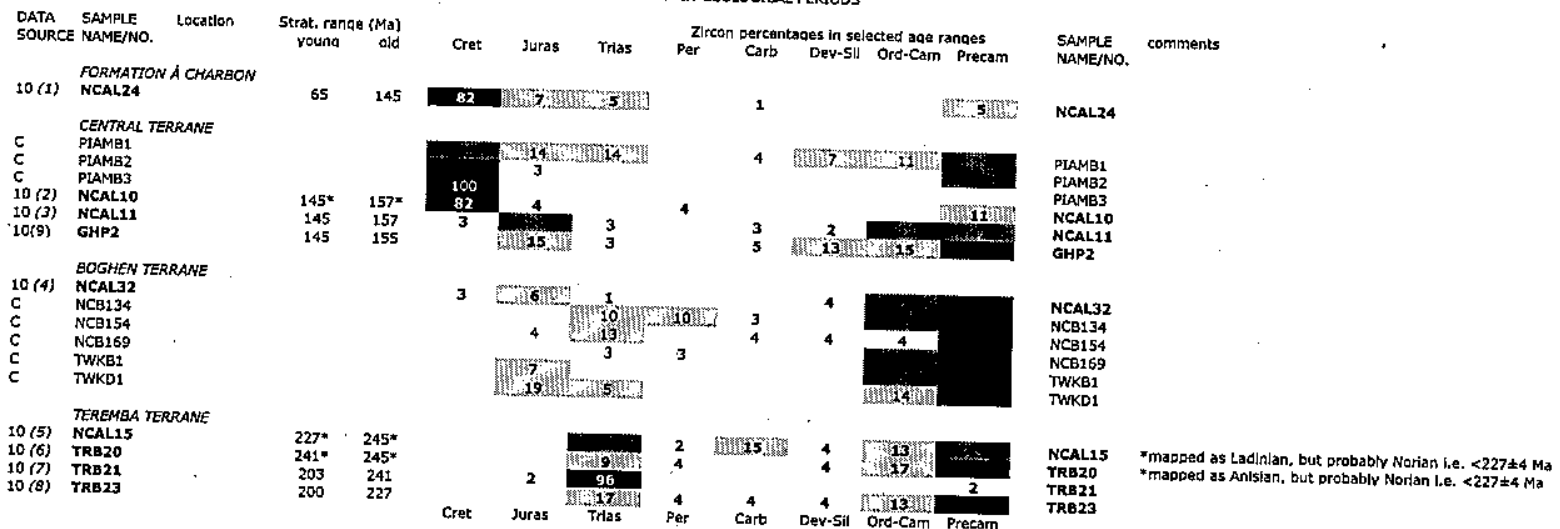

TABLE SB: OETRTTAL 2IRCON AGE DATA FOR NEW ZEALAND EASTERN PROVINCE TERRANES AND NORTHLAND ALLOCHTHONS: PERCENTAGE PROPORTIONS IN GEOLOGICAL PERIODS

A NORTHLAND MOUNT CAMEL ALOCHTHONS

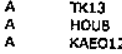

3 WAOEKA TERRANE

PAHAU TERRANE

PAHAU TER

HUN4
CPOS

RAKANA TERRANE

RBW1
OTO1

OTO2

$\mathrm{NGO2} 2$
$\mathrm{NGO2}$

PUD1
Balmatann

Balma
SEL4
PAR2

Avlemere

BMOX35

Kakahu Terrane

KaX35
Akatarawa Terrane

Akataraw

WAIPAPA TERRANE

144

W1

WS

TWXX1

SPE1

BLU8A
BOIX31

PKTNX1

STEPH1

CAPLES TERRANE

OUOX1
VON2
WRLE1

DUN MOUNTALN-MAITAI TE

STPH12

CST10

MURIHIKU TERRANE

HURW4

ROAR2
PIOX5

PIOX5

GROOK STREET TERRANE

BAR2A

$95 \quad 108$

T MIII!n!

[an 16 mat

$\begin{array}{ll}4 & 3 \\ 2 & \end{array}$

TK13
HOUS
KAEO12

$240 \quad 150$

$\mathbf{t 4 2 0}$

$145 \quad 160$

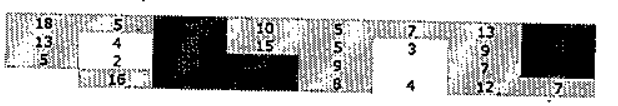

Ethelton
HUUN4
CPDS
RUX2

$\begin{array}{ll}205 & 2 \\ 220 & 2 \\ 220 & 230 \\ 220 & 2 \\ 220 & 230 \\ 220 & 235 \\ 251 & 2 \\ 251 & 260 \\ 251 & 260\end{array}$

220
230
230
230

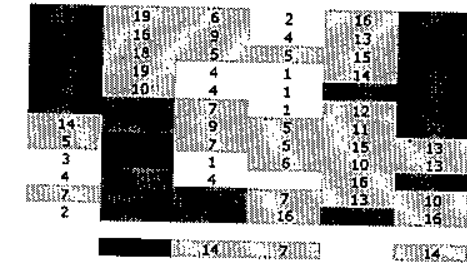

RBW1
OTO1
OERM2
NEO2
NGO2
NGO2
PUD1
Balmacos
SEL4
PAR2
AVIemore
KLROW
BMOX35

251
251
251

4 m11\%

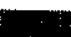

TAKA10

133148 3) 162

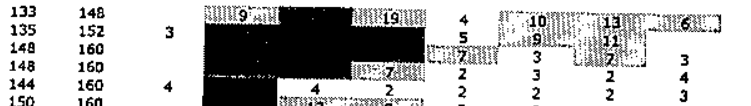

1 trolord (1992)

1 ltederd (1992)

3 Cartood ot ad (1999)

4 Compood et ad. (2002)

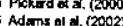

7 Wendras of at. (2004s)

this work, data highllghtled in bold hpe

A Adarns, unpulisished dato

Italle numbers in brackets refer to localltiv numbers of thls study rTable 11

180500 


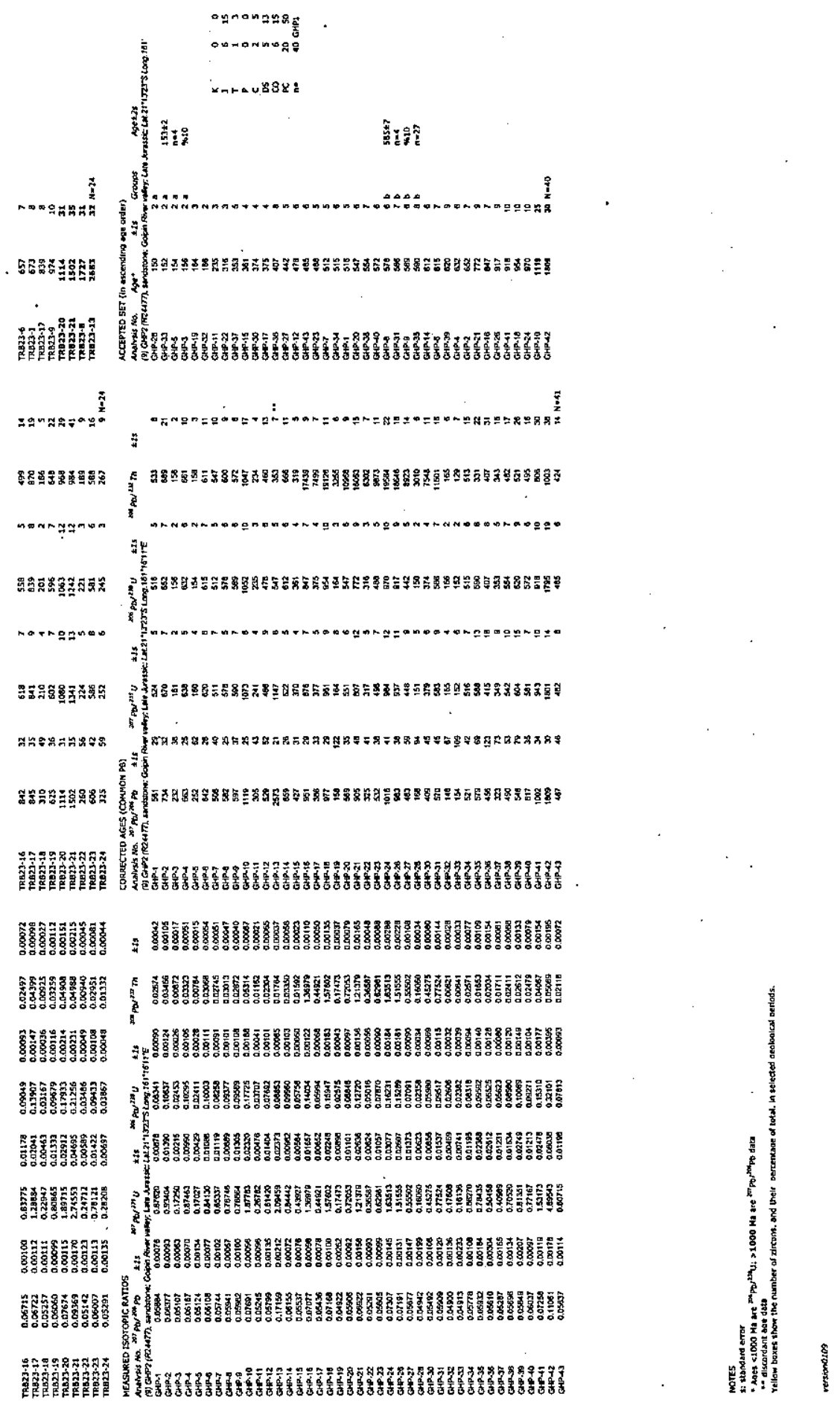

